1979

\title{
Crossroad of Empire: The Church and State on the Rio Grande Frontier of Coahuila and Texas 1700-1821
}

Felix D. Almaraz Jr. Center for Archaeological Research

Follow this and additional works at: https://scholarworks.sfasu.edu/ita

Part of the American Material Culture Commons, Archaeological Anthropology Commons, Environmental Studies Commons, Other American Studies Commons, Other Arts and Humanities Commons, Other History of Art, Architecture, and Archaeology Commons, and the United States History Commons

Tell us how this article helped you.

This Article is brought to you for free and open access by the Center for Regional Heritage Research at SFA ScholarWorks. It has been accepted for inclusion in Index of Texas Archaeology: Open Access Gray Literature from the Lone Star State by an authorized editor of SFA ScholarWorks. For more information, please contact cdsscholarworks@sfasu.edu. 
Crossroad of Empire: The Church and State on the Rio Grande Frontier of Coahuila and Texas 1700-1821

\section{Creative Commons License}

\section{(c) (1) \&}

This work is licensed under a Creative Commons Attribution-NonCommercial 4.0 International License 


\section{CROSSROAD OF EMPIRE}

\section{The Church and State on the Río Grande Frontier of Coahuila and Texas, $1700-1821$}

By

FELIX D. ALMARAZ, JR.

with a preface by Richard E. W. Adams

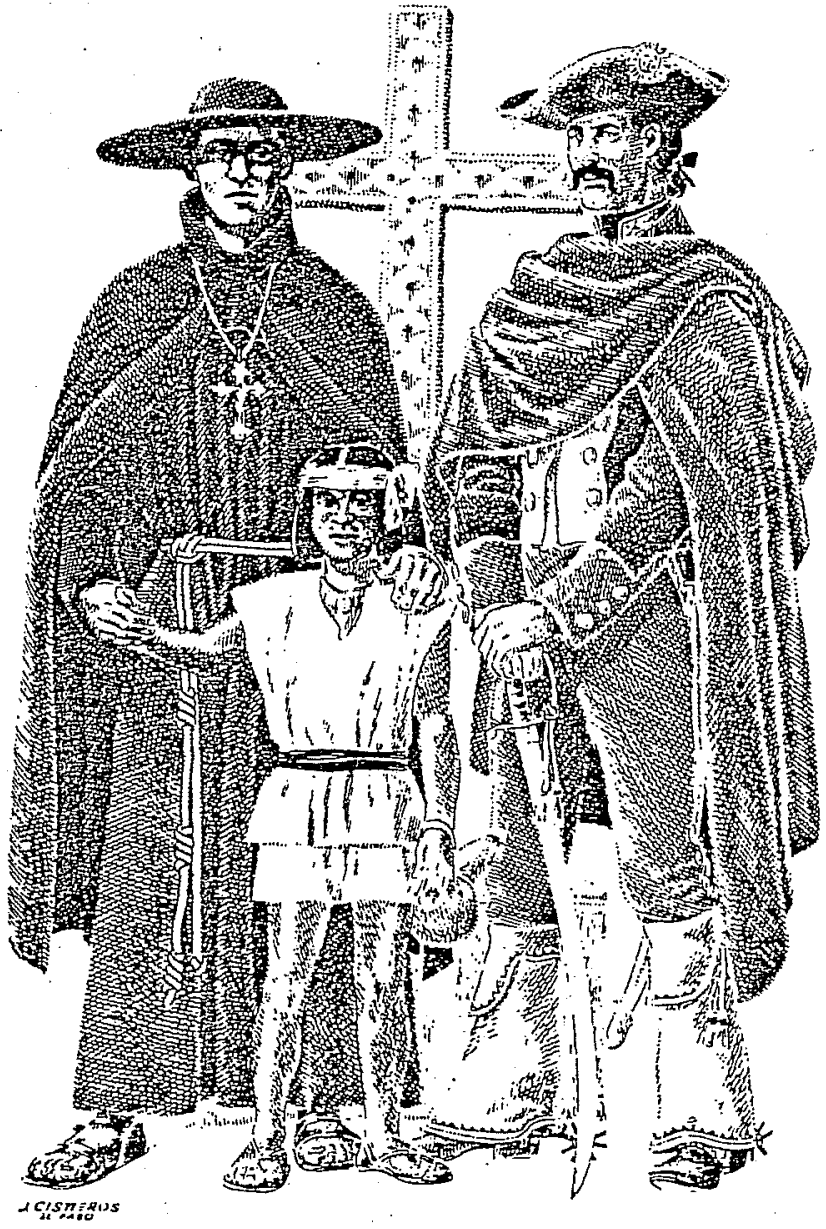

Center for Archaeological Research

The University of Texas at San Antonio

Archaeology and History of the San Juan Bautista Mission Area, Coahuila and Texas

Report No. 1 


\section{Center for Archaeological Research}

The University of Texas at San Antonio

78285

Thomas R. Hester, Director

Archaeology and History of the San Juan

Bautista Mission Area, Coahuila and Texas

This series of publications presents information gathered from archaeological investigations and historical research at the Spanish mission complex in the area of Guerrero, Coahuila, Mexico.

No. 1 (1979) Crossroad of Empire: The Church and State on the Rio Grande Frontier of Coahuila and Texas, 1700-1821. By Felix D. Almaraz, Jr. 77 pages. $\$ 5.00+.28$ tax for Texas residents.

No. 2 (1979) Inventory of the Rio Grande Missions: 1772; San Juan Bautista and San Bernardo. Translated and edited by Felix D. Almaraz, Jr. 70 pages. $\$ 5.00+28$ tax for Texas residents.

No. 3 (1979) Ethnohistoric Notes on Indian Groups Associated with Three Spanish Missions at Guerrero, Coahuila. By T. N. Campbe17. 76 pages. $\$ 5.00+.28$ tax for Texas residents.

No. 4 (1981) Guerrero, Coahuila, Maxico: A Guide to the Town and Missions. By Jack. D. Eaton. Spanish translation by Wanda Kaufmann. 41 pages. $\$ 5.00+.28$ tax for Texas residents.

Please add postage and handling for above publications as follows: 1-2 reports, $\$ 1.25 ; 3$ reports, $\$ 1.50 ; 4$ reports, $\$ 2.00$. 


\title{
CROSSROAD OF EMPIRE \\ THE CHURCH AND STATE ON THE RIO GRANDE FRONTIER \\ OF COAHUILA AND TEXAS, \\ $1700-1821$
}

\author{
by \\ Félix D. Almaráz, Jr. \\ with a preface by Richard E. W. Adams
}

\begin{abstract}
Center for Archaeological Research The University of Texas at San Antonio ${ }^{\circledR}$ Archaeology and History of the San Juan Bautista Mission Area, Coahuila and Texas

Report No. 1
\end{abstract}

1979

Third Printing 1984 
TABLE OF CONTENTS

Page

List of Figures. .................... . . . . . . . . . . List of Tables ......................... . . . . . . . . . . Preface................................ iv Introduction ....................... 1 Early Frontier Expansion in New Spain. . . . . . . . . . . . 1 Settlement of Coahuila . . . . . . . . . . . . . 2 Patronato Real: Genesis of Union of Church and State. . . . . . . . 2 Order of Friars Minor. . . . . . . . . . . . . . 3 Apostolic College of Santa Cruz de Queretaro............ 3 The Frontier Mission: An Evolutionary Process . . . . . . . . . . 5 Franciscan Foundations of the Rio Grande . . . . . . . . . . 6 The Presidio: Complementary Component of Missionary Expansion . . . . . 8 The Initial Decade: Progress and Recession. . . . . . . . . 11 The Missions After a Quarter Century: Renewal of Effort . . . . . . . 12 Clash of Church and State. . . . . . . . . . . 15 Presidial Settlers.................. . 17 Mission Land Grants: The Act of Possession. . . . . . . . . . . . . 18 Friar Terreros and a New Generation of Frontiersmen. . . . . . . . . . 19 The Crossroad at Mid-Century . . . . . . . . . . . . . 22 Expansion from the Rio Grande. . . . . . . . . . . . . . . 24 The Bourbon Reforms. . . . . . . . . . . . . . . 26 Transition: Queretaran Withdrawal and Jaliscan Succession . . . . . . 27 The Visit of Friar Morfi . . . . . . . . . . . . 30 The Last Missionaries: The Friars of Pachuca. . . . . . . . . . . . . . 34 
Table of Contents:

Page

The Bishopric of Nuevo Leon and the Pachucans. . . . . . . . . 36

Secularization: Exemption for the Rio Grande Missions . . . . . . . . 38

The Presidio: Bastion of the Crossroad. . . . . . . . . . . . 38

Secularization: A Perennial Complaint . . . . . . . . . . . 40

The Rio Grande Missions at the Turn of the Century . . . . . . . . . 41

The Revolt of Miguel Hidalgo . . . . . . . . . . . . . 43

The River Crossroad on the Eve of Mexican Independence . . . . . . . 45

The Crossroad in Retrospect. . . . . . . . . . . . . . 46

Notes....................... . . . 54

Bibliography ..................... 64 


\section{LIST OF FIGURES}

Figure

1. A Franciscan Friar at Mission San Bernardo. . . . . . . . . . 4

2. Map of Presidio San Juan Bautista in.1767 . . . . . . . . 25

3. A Franciscan Missionary and a Presidial Captain, with a Native Boy. . . . . . . . . . . . . . 39

4. Frontispiece and Title Page of Novena Booklet Used at Mission San Juan Bautista . . . . . . . . . . . . .

\section{LIST OF TABLES}

Table

1. San Juan Bautista, 1706 . . . . . . . . . . . . 48

2. San Bernardo, 1706. . . . . . . . . . . . . 50

3. San Juan Bautista, 1727 . . . . . . . . . . . . . 51

4. San Bernardo, 1727. . . .. . . . . . . . . . . . 52

5. Mission Population Statistics, $1738 \ldots \ldots 53$ 


\section{PREFACE}

The monograph being published here is the first in a series of data-oriented reports derived from the archaeological and ethnohistorical project centered on the modern town of Guerrero, Coahuila, Mexico. To our gratification, the project produced a great deal of information. We have decided to meet the problem of adequate publication of the results in two ways. The first is by a volume of essays which aim at synthesizing the various aspects of the data and drawing conclusions from it. This single volume will be published elsewhere and is now (1979) in preparation. The other means of publication is by a series of technical reports which will present the detailed data and information upon which we have based the essays and conclusions. It is not that the report series will lack conclusions, but its primary aim is to present information. This study by Dr. Almaraz begins the report series.

The town of Guerrero, Coahuila, Mexico, was formerly known as San Juan Bautista del Rio Grande del Norte and developed from the principal mission of a group of 18th century religious establishments located there. A presidio was founded near the missions and the whole made up a principal outpost of Spanish colonial authority on the frontier of northern New Spain. The location was determined partly by the lakes once present in the vicinity, and by the shallow fords of the Rio Grande not far away. The Gateway Project was set up by The University of Texas at San Antonio to do both archaeological exploration of the zone as well as historical research into the background of the missions. We accomplished a great.deal of historical and prehistoric archaeology. Thomas R. Hester was in overall charge of the archaeological work. Jack D. Eaton directed excavations at two of the four mission sites, San Bernardo and San Juan Bautista. Parker Nunley and Chris Nunley concentrated on the survey of prehistoric sites, covering an area of roughly 25 kilometers up and down the river from Guerrero, and on both sides of the Rio Grande. Reports from all of these scholars, along with specialist studies, will follow in this series.

The ethnohistorical work was directed by Thomas C. Greaves. Thomas N. Campbe11 played a major role in studying the ethnohistory of the mission Indians. Félix D. Almaráz carried out historical research. The study by Dr. Almaráz of the history of the San Juan Bautista missions is the first in our series of reports. We believe that it will prove of considerable interest to historians, archaeologists and others with an interest in the colonial history of northern Mexico and Texas.

The project was generously supported by funding from the National Endowment for the Humanities, the Catheryn $0^{\prime}$ Connor Foundation and the Sid Richardson Foundation. We worked under a contract with the Mexican governmental agency, Instituto Nacional de Antropologia e Historia, through its dependency, Monumentas Coloniales. Arquitecto Sergio Zaldivar was our contact and extremely helpful and encouraging at every step of the project. Zaldivar also managed to obtain the substantial aid of the Secretaria de Obras Publicas in the consolidation of the San Bernardo Church, and ran interference for us in the toils of the Mexican bureaucracy. Administrators at The University of Texas at San Antonio, especially Mr. Everitt Mahon, then the Vice President for Business Affairs, were most supportive, providing vehicles and other aid. Former President Peter T. Flawn gave us every aid in our endeavors and took a very personal interest in our work. The town of 
Guerrero, Coahuila, and its two mayors, Don Victoriano Garcia P. and Don Ricardo Perez Treviño, were at all times most helpful to the project. To Dr. Farias de los Santos who provided rent-free housing during the 1975 field season we express our gratitude. Srta. Jesuseña Flores Rodriguez generously provided us rent-free housing for the 1976 season. She aided the project greatly and made us feel much at home with her hospitality. Sr. Salvador Gonzales Sierra, owner of the Cooperativa Familias, is to be thanked for his friendship, good humor and continual encouragement. Others helped the project in many ways, and their contributions are recognized elsewhere. However, we must mention here Mr. Boone Powell of San Antonio, who first suggested the project to us, and was instrumental in getting it going in its first stages. To all of the above we are very gratefut, and hope that these studies live up to their expectations.

\author{
R. E. W. Adams \\ Project Director \\ San Antonio, Texas \\ Apri1 20, 1979
}




\section{INTRODUCTION}

In the 17th century, owing to native resistance and aggression and the relative weakness of isolated communities, Spanish expansion of the northeastern frontier in the direction of the Rio Grande progressed slowly. By mid-century, however, mainly due to mineral discoveries, the number of explorations and settlements increased sufficientiy to warrant the creation of the Province of Coahuila. In 1687 the first governor, Alonso de León the younger, designated a presidio in the town of Monclava as the provincial capital. ${ }^{1}$

\section{EARLY FRONTIER EXPANSION IN NEW SPAIN}

The official founding of Coahuila, the placename of which signified lugar bajo or lowlands to the inhabitants, ${ }^{2}$ demonstrated the extent to which two agencies of frontier control contributed to colonial expansion--the presidio, which was not entirely a distinctive institution in the line of advance, and the mission, which clearly was unique in the northward movement. ${ }^{3}$ At the close of the 17 th century, the establishment of these institutions on the Rio Grande frontier of Coahuila, although incipient, visibly depicted the commitment of soldiers and missionaries to implement an imperial policy of controlling the region and its native people by armed force or gentle persuasion. As the initial decade of the 18th century unfolded, the goals of the church and state, uniting on the west bank of the middle Rio Grande, conveyed geopolitical importance to the area as a crossroad of empire.

The Spaniards' determination to extend the limits of territorial occupation eastward stemmed from external and internal factors. In the $1680 \mathrm{~s}$, the presence of French interlopers on the Texas coast provided the external stimulus for Alonso de León to lead five expeditions across the Lower Rio Grande Valley in search of the foreigners. ${ }^{4}$ The internal factor which accelerated further development of the frontier was the arrival of a new group of Franciscan missionaries from the recently established Apostolic College of Santa Cruz de Querétaro. ${ }^{5}$ Although De León's primary objective was exploration for the purpose of evicting French intruders from the borderlands, a significant result of that activity was the founding in 1690 of the first Franciscan missions in the piney woods of east Texas. Administrative superiors of the Queretaran college, responding to the needs of the state, assigned missionary personnel to this remote outpost. ${ }^{6}$

Given the vicissitudes of the Texas missions--compounded by problems of overland communication, inadequate supply service, international rivalries and unpredictable native loyalties-- the government of New Spain recognized Coahuila as a practical crossroad and resource center to support colonial expansion and defense. The outcome was a realignment of philosophical considerations to coincide with political requirements in the founding of a cluster of Franciscan missions and a presidio on the west bank of the Rio Grande. 


\section{SETTLEMENT OF COAHUILA}

In the northern advance, the Queretaran friars agreed to share the missionary field with fellow Franciscans from the ecclesiastical Province of Santiago de Jalisco (Guadalajara) who had been early pioneers in Coahuila. A prototype of the Franciscan frontiersman was Father Juan de Larios of the Jaliscan Province, who in 1675 attained recognition as being the first European to cross the Rio Grande into Texas in search of prospective native converts, thus setting in motion the gradual approach to the river valley. In dividing the vast missionary expanse with the Franciscans of Jalisco, the Queretaran friars accepted responsibility for pushing the line of settlement toward the middle Rio Grande.?

The Queretarans' northward progress eventually brought them into contact with cultural groups, mostly hunters and gatherers, whom the Spaniards identified by the general appellation of Coahuiltecas. Military and missionary explorers of the borderiands described these tribes as aggressive, belligerent, and nomadic. Although some Coahuiltecan groups practiced the custom of natural monogamous union, the others virtualiy ignored such convention. Indicative of the hunting-gathering tendency of these peoples, as minimum protection in the unsheltered environment and as a mark of distinction between the sexes, the men covered their bodies with buffalo hide and the women used deer skin. Their onty weapons were bows, arrows and lances with which they either hunted or defended their humble dwellings. For sustenance they relied upon wild game, fruits and roots. Nomadic inclinations notwithstanding, each group occupied a definite territory which the warriors vigilantly guarded, permitting only trusted allies to enter. Aggression seemed so characteristic of their behavior that for the most insignificant transgression they immediately resorted to combat as a solution. ${ }^{8}$ To the friars of Querétaro, the Coahuiltecas became an important target group of Spanish indoctrination.

\section{PATRONATO REAL: GENESIS OF UNION OF CHURCH AND STATE}

By the beginning of the 18th century, the union of church and state, as manifested by the interdependence of missionaries and soldiers on the frontier, rested on a firm foundation embedded in Spanish history--the patronato real. Pope Julian II, in a document signed in 1508, promulgated the special relationship of the church and state in Spain and in the New World colonies. As the centuries progressed, the royal patronage signified that the crown would supervise and encourage the spread of Christianity and oversee the maintenance of the church; the church in reciprocity, would uphold the aims of the state and permit political intervention in ecclesiastical matters. In actual practice, the patronato real became a legally regulated grant issued by the church through which it bestowed certain rights, privileges and obligations in gratitude to its generous benefactor, the crown of Spain. Thus, in the conquest, exploration and colonization of Spanish North America, the patronato real enabled the state to exercise control over the colonial clergy. The patronage arrangement allowed the monarch to be the papal representative in New World interests, and the members of the clergy unquestionabiy accepted the right of crown supervision of church affairs. The king, through the power of appointment, was the de facto leader and champion of the church in the Indies, and the clergy became an extension of the bureaucracy, "a loyal auxiliary" of the state. As the union of church and state in New Spain expressed itself in 
the patronato real, bishops and archbishops performed temporal duty as viceroys during unforeseen emergencies. ${ }^{9}$

\section{ORDER OF FRIARS MINOR}

Against the background of the royal patronage, the missionary endeavors of the Franciscans in the borderlands assumed special significance in light of their philosophical and historical tradition. Founded in 1210 by Francis of Assisi, the Franciscans, in deference to the biblical inspiration of being the "least of the brethren" (Matthew 25:40-45), called themselves Friars Minor. As such, they voluntarily identified with the lower classes of society. In the friars' ministerial work, the temporal world became their cloister. Normally they labored for their sustenance, but if work opportunities were non-existent they begged, thus becoming "true mendicants." Gradually, the Franciscans, depending on the choice of vocation of the individual members, organized three orders to foster the spirit and personality of their founder. Into the missionary frontier of northeastern New Spain went members of the First Order of Friars Minor; they wore blue-grayish habits and cowls, tied with white cord. Within the ranks of the First Order were ordained priests and religious lay brothers. From the beginning, the Franciscans, with varying degrees of perfection according to their capacities and talents, accepted the guidance of three vows: the vow of poverty, whereby as individuals they renounced all worldly possessions but not necessarily the use of material things, since like other human beings they needed food, clothing and shelter; the vow of chastity, whereby they promised to live a life of celibacy, virtue and purity; and the vow of obedience, whereby they pledged themselves to go wherever assigned and to obey the commands of the respective religious superiors. The three knots in the Franciscan cord were visible reminders of these vows. 10

\section{APOSTOLIC COLLEGE OF SANTA CRUZ DE QUERÉTARO}

The missionaries who advanced toward the middle Rio Grande manifested the spirit of adventure that St. Francis advocated. They seemed willing to take a chance to convert the natives, even at great personal risk to their lives. They feared no danger and at times appeared to welcome it. The Franciscans of the Apostolic College of Santa Cruz de Querétaro were imbued with vigorous missionary zeal. To understand and appreciate the Franciscan effort on the northeastern frontier, a brief survey of the Queretaran college is appropriate. Founded in 1683, Santa Cruz de Querétaro was the first in a series of similar institutions for the training of missionaries for frontier service. The system of government for the new college was replete with checks and balances. The immediate administrative superior was the Franciscan Commissary Genera 1 of New Spain, who was obligated to visit and inspect the college every three years and to preside over the capitular elections, although these responsibilities might be performed by a personal delegate. The religious community of Querétaro, the membership 1 imited to 30 , normaliy recruited friars from among the priests and lay brothers of the Franciscan provinces of Spain and of the Americas, but the college accrued the constitutional prerogative to confer the habit to candidates for the Order provided they fulfilled all requisites of age and spiritual and physical fitness for missionary assignment. Locally, an administrative officer, called guardian, governed the college for a term of three 


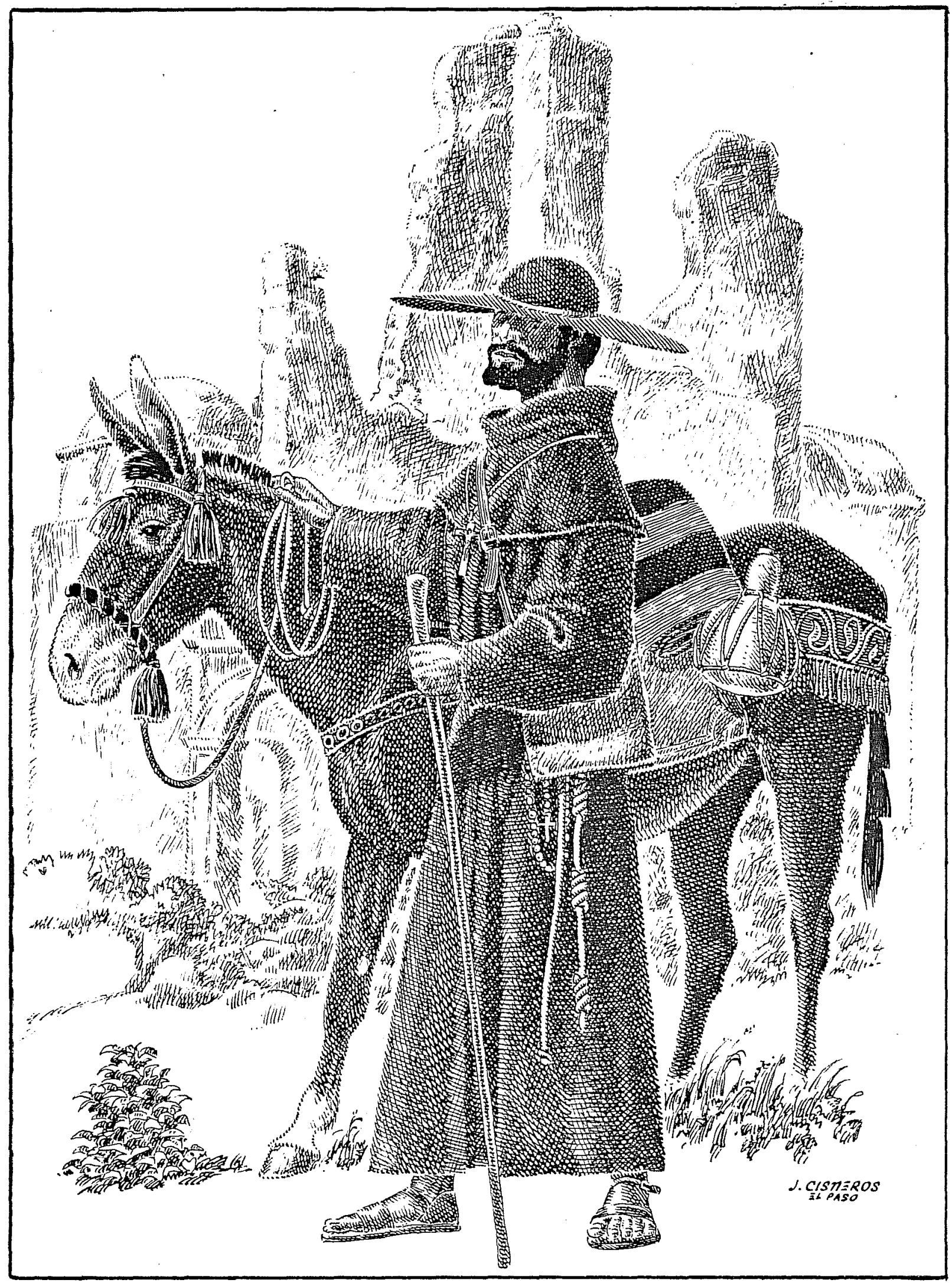

Figure 1. A Franciscan Friar at Mission San Bernardo. Drawing courtesy of the Bexar County Historical Commission. 
years, assisted by a council of four discreets chosen from among the priests with the most seniority in the order. It was the responsibility of the guardian and the council to administer the operating rules of the college, to evaluate the fitness of character of candidates (both from within and without the community), and to expel from the college and return to their ecclesiastical province those friars found unworthy or unsuitable for the objectives of Santa Cruz. The guardian and the discreets elected a vicar, who supervised the college and its operations in the absence of the chief administrator.11

An important element in the enterprise was the curriculum. The college founder, Father Antonio Llinás, purposely selected Querétaro because of its proximity to the unconverted natives and its environment of solitude and retirement.

Religious discipline was quite strict [wrote the Franciscan scholar Pius Barth]; the missionaries were to be motivated spiritually in the difficult and dangerous life ahead of them . . Hence, the community exercises of mental prayer, conventual mass, divine office, and the common life in recreation, meals and regular hours for discussions, lectures, silent study, and retirement were designed to build the morale as well as the mind and body of inexperienced and seasoned missionaries. 12

At the start of the project, since most of the collegians had already been ordained priests, the founder received prompt support for his program of strict discipline and daily regimen. Apart from limited duties in preaching, administering the sacraments and visiting the sick, the priests devoted most of their time to conferences and study. The curriculum reserved the morning hours for lectures on Indian languages, while the afternoon classes included conferences "on the art of converting, catechizing, and instructing" the natives. Integrated into the curriculum were lectures on moral theology, mission administration and occasional discussions on ethnology or anthropology. On balance, the training given to missionaries at Santa Cruz de Querétaro was both spiritual and educational, with emphasis on the linguistic and social-moral aspects. 13.

The college guardian assigned friars for spiritual duty among the faithful in the proximity and for missions in the frontier. Franciscans at established missions within reasonable distance from Querétaro remajned subject to the guardian, until such times as state and church authorities agreed on a modification. Whenever the friars went into "pagan country, "technically they worked under the leadership of the commissary. of the missions, who supervised areas and personnel until the frontier was considered a settled region. After 1693, however, the circumstances of frontier service in Coahuila and Texas (and later in the northwestern regions) required that missions and missionaries be under the jurisdiction of the college guardian from the onset. In the missionary field itself, a father-president, subject to the directives of the college, administered day-to-day operations. 14

\section{THE FRONTIER MISSION: AN EVOLUTIONARY PROCESS}

As originally planned in the history of the church, beginning with conditions in medieval Europe, a "mission" was first and foremost an activity; it was not 
exclusively a building or a place. In New Spain, as frontiersmen extended the outer limits of territorial occupation, itinerant missionaries in the vanguard found themselves distantly removed from centers of urban settlement. Gradually, as the frontier continued to expand, a mission, including a church building and a complex of structures, became an institutionalized activity as well as the spiritual goal for the natives. 15.

By the 18th century, coinciding with the Spaniards' northward movement toward the Rio Grande, the missionary methodology for converting Indians to Christian$i$ ty and to royal fidelity had become standardized as a "mission system" through an intricate pattern of laws, rules and traditions. The process began with the founding of a mission (misión) for gentiles, natives who were presumed to lack formal religion. Ideally, the methodology progressed through several graduated stages-reducciones (congregations) that confined the natives to a definite. area; conversiones (conversions), a program of religious instruction in the basic concepts of Christianity; doctrinas (doctrines) for those natives who showed special aptitude in comprehension and practice of the new religion, and finally curatos (curacies) which signified the transition from temporary mission to permanent parish under the care of the diocesan clergy. For the mission Indians the designation of curato denoted a change of status from wards of the state to gente de razón with law-living habits and responsibilities. I6 The perfect timetable for a mission required 20 years; however, the vicissitudes of frontier experience, as evidenced on the Rio Grande, frequently delayed the schedule of progress.

\section{FRANCISCAN FOUNDATIONS OF THE RIO GRANDE}

In the summer of 1699 , a sma 11 band of Queretaran friars, accompanied by a squad of presidial soldiers, approached the region south of the Rio Grande in search of suitable locations for missions. Destined to perform key roles in the early history of the area were Fathers Diego Salazar, Francisco Hidalgo and Antonio 01 ivares. Among their new establishments was Mission San Juan Bautista, founded on the feast day of St. John the Baptist (June 24) and situated near the Rio Sabinas. 17 In less than six months, Friar 01 ivares negotiated with church and state officials for permission to concentrate the missionary effort closer to the Rio Grande. 18

In late December 1699, with a military escort led by Sergeant Major Diego Ramón, the Franciscans, impressed by convenient, low-water river crossings, explored the upland terrain for potential mission sites. On the first day of the new year 1700, after naming the area the Valley of the Circumcision (January 1 is the Feast of the Circumcision), the friars and soldiers assisted Father 01ivares, the commissary of the group, in the founding of the initial mission on an elevated knoll west of the Rio Grande. Inspired by the ecclesiastical nomenclature of a promising beginning earlier on the Rio Sabinas, Olivares, to symbolize a continuity of effort, acclaimed the mission as San Juan Bautista. ${ }^{19}$

To provide temporary protection from the elements, the Spaniards, using mainly branches and straw, constructed rudimentary shelters, including a church and living quarters for the friars. For several. months the three priests-01 ivares, Hidalgo and Salazar--shared one small grass hut which they found "grossly inadequate." 20 Personal discomfort notwithstanding, the military 
approved of San Juan Bautista's location, because it was far removed from the Rio Grande and the danger of floods, yet contiguous enough for sentries to guard the nearby crossings. The highland terrain of the Rio Grande-Rio Sabinas basin was generally arid, intersected by irregular, rocky hills, covered with prickly-pear cacti, creosote bushes, mesquite trees and lechuguilla (a variety of agave). The soil of the drainage plain, where 01 ivares and Ramón established Mission San Juan Bautista, was very fertile and could be irrigated with water from upland natural springs. ${ }^{21}$

Cognizant of local resources capable of supporting modest expansion, on March 1 , 1700, 01 ivares founded a second mission--San Francisco Solano--adjacent to arable land in the vicinity; the exact location of this mission is now obscure owing to a subsequent transfer of building sites. At the initial founding of San Francisco Solano, named in honour of a 17 th century friar and saint, an interpreter, Félix Sánchez, asked the indigenous tribes if the establishment of a mission conformed to their wishes. According to Diego Rámon, who witnessed the formal act of foundation, the congregation of 65 natives signified affirmation of the fundamental step in the mission process. Father 0livares, ringing a bell to attract attention, began instruction in the four basic prayers of Christianity, ending the lesson with a hymn, the Alabado, in honour of the Blessed Sacrament and the Virgin Mary. Olivares then celebrated a Mass of Thanksgiving, keenly aware that his congregation included more curious observers than active participants. In temporal matters, the natives pledged obedience to the officials of their mission community. 22

After the formalities, Sergeant Major Ramón, having fulfilled the objectives of his assignment, returned with the soldiers to Monclova, the provincial capital, leaving the Franciscans on an exposed periphery. Without the shield of military protection, native aggressors, mainly a group called Tobosos, periodically raided the missions' seminal livestock. At other times they intimidated the new converts, either by persuading the more docile to flee into the wilderness or by kidnapping women and children. Father 01 ivares petitioned the governor of Coahuila, Francisco Cuervo y Valdez, to provide permanent military security for the missions. Sympathetic to the plight of the friars, the governor, a career administrator, responded with a temporary expedient by dispatching an experienced frontiersman, José de Urrutia, to ward off native aggression. Despite Urritia's skill and prowess, one man could not be an effective deterrent. In the spring of the following year, the friars capitalized on a new opportunity to resolve the defense problem when the Bishop of Guadalajara, Felipe Galindo Chávez Pineda, inspected the northeastern limits of his diocese within which were the missions of Coahuila. Stopping at San Juan Bautista to consecrate the mission bells, Bishop Galindo informally conferred with the friars on needs and priorities for securing and extending apostolic activities. Encouraged by the bishop's visit, Father 01 ivares, with the consent of his brother friars, journeyed to Mexico City for an audience with Viceroy Jose Sarmiento de Valladares, the count of Moctezuma y Tula. The outcome of 01 ivares' visit to the viceregal court was two-fold: he obtained the necessary military protection, and also enlisted the support of the viceroy's wife in furthering the work of the Queretaran Franciscans on the frontier. Of immediate significance to the defense of the Rio Grande missions was the deployment of a mobile cavalry unit of 30 soldiers in July 1701, commanded by Sergeant Major Diego Rámon. 23 
The Spaniards' military presence at the river passage, assuring security and assistance for the missions, clearly demonstrated the union of church and state in the pursuit of mutual goals. On the return trip to the frontier, Father 01 ivares stopped at Santa Cruz de Querétaro, undoubtedly for spiritual renewal and for an opportunity to discuss expansion plans with the outgoing college guardián, Francisco Hidalgo. Accompanied by two new missionaries, Jorge de Puga and Alonso Gonzälez, Friar 01 ivares proceeded northward to the Rio Grande. According to the Franciscan historian Fêlix Espinosa, contemporaries viewed San Francisco Solano as a recreation center because of material goods, procured in Mexico City, with which 07 ivares furnished the mission; these were the resuit of the generosity of the viceroy's wife, the Duquesa de César. "Each day," wrote Espinosa, "the Indians decorated the church with branches and flowers, and attended doctrinal classes in the morning and afternoon." 24

Confident in the knowledge of subsidiary support, the Franciscans determined to enlarge their missionary commitment by establishing a third outpost of empire in the immediate environment. At a distance of "two musket shots" southeast of San Juan Bautista, early in 1702 the friars founded Mission San Bernardo, named in deference to the devotion of the Duquesa de César who donated the church furnishings. By May, the resident missionary, Fray Alonso Gonzalez reported 400 natives under instruction. 25

\section{THE PRESIDIO: COMPLEMENTARY COMPONENT OF MISSIONARY EXPANSION}

The concentration of three missions within a definite radius, each competing to serve the spiritual welfare of interrelated Coahuiltecan tribes, inevitably contributed to a realignment of colonial settlements in 1703. A noticeable sign of change was the appointment of Matias de Aguirre as governor of Coahuila. This transition in office, in turn, led to the upgrading of the mobile cavalry patrol into a permanent garrison, designated presidio San Juan Bautista del Rio Grande, commanded by the governor's relative, Captain Pedro Buenaventura de Aguirre. Located at the center of unappropriated mission lands, the presidio acquired an adequate plaza de armas around which the soldiers initially constructed 10 flatroofed adobe and stone houses, the most spacious of which was the commandant's office and residence, the capitania, at the northeast corner. The complex also included barracks for unmarried presidials, supply rooms and an enclosure for the cavalry horses. 26

In the first decade of the 18th century, the permanent status of Presidio San Juan Bautista del Rio Grande, safeguarding the adjoining missions, created a social climate of cooperation and goodwill among representatives of church and state. Admittedly, the uncertainties and dangers of frontier living sustained that spirit of interdependency and friendship. Illustrative of this tendency was Captain Aguirre's assistance, with manpower and materials, in the building program at the nearby missions. By September 1703, the presidial laborers completed the initial phase of construction. First, San Juan Bautista, built of double adobe walls, measured 30 pasos ( 13.5 feet) wide, with two side altars forming the nave of the church. Next, San Francisco Solano, also with walls of double thickness, was 28 pasos long but much narrower (6 pasos), with a space between the pews and the main altar. Finally, the dimensions of San Bernardo with double walls like the others, were 33 pasos (16.5 feet) in length and 16 pasos ( 8 feet) in width. 27 
Not surprisingly, the establishment of a presidio, with three missions clustered around $i t$, increased human demands upon the natural resources of the area, particularly water, arable fields and grazing land. As a consequence, the scarcity of water, among other factors, motivated the neophytes of San Francisco Solano to flee into the hinterland. Father 0livares, assisted by Francisco Hidalgo, the former guardian of Santa Cruz, retrieved some of the fugitives, mostiy Xarames, and resettled them at a site 16 leagues (nearly 42 miles) west of the Rio Grande, which they called San Ildefonso. Five years later, when the mission converts escaped to avoid the hostility of the Tobosos, the Franciscans returned the church ornaments to the Rio Grande and reestablished San Francisco Solano at San Jose, three leagues ( 7.8 miles) north of the more historic outposts, where the mission remained for a decade. In 1718, following the recommendation of Father 01ivares, the viceregal government authorized the suppression of San Francisco Solano and its transfer eastward to become the genesis of the noted Texas institution, Mission San Antonio de Valero. ${ }^{28}$

Aside from defense and material assistance, both of which were vital for the success of the Rio Grande enterprise, the relationship of the missionaries and soldiers manifested itself in the social interaction designed to influence the 1 ifestlyes of the natives. According to Espinosa the historian, the natives assembled at the church every morning and evening for prayer recitation, following in unison the priest's lead (or in his absence, the fiscal, a native who was wel1 trained in Christian doctrine). The participants recited a11 prayers in Castilian, the second language in which the mission Indians had acquired oral communication skills. The friars also involved newly-arrived gentiles, who, although not as advanced in instruction as Christian converts, nonetheless took part in the prayer services as catachumens. Prior to each assembly, the fiscal and an assistant rang the church be11; then they visited the Indian quarters, summoning adults and children, excusing only the infirm from attending religious services. Just before the priest began the instruction the native leaders reported the absentees. In the event that a native feigned illness in order to avoid instruction, at the conclusion of the doctrinal lesson the fiscal exercised delegated authority by bringing the truant before the congregation. Forcing the individual to kneel in front of the crucifix at the cemetery, the fiscal administered four or five whiplashes on the truant's back as an object lesson to a11. observers. Given the fact that gentiles were beginners in comparison to the converts, the resident friar at the mission reserved time in the day for individual instruction. With the aid of an interpreter, the missionary taught the Indians one at a time, emphasizing the basic concepts of Christianity and gradually preparing them for baptism. ${ }^{29}$

The solemn baptism of the native children was a special occasion for social participation by the presidial families in the religious affairs of San Juan Bautista and San Bernardo. On such days, as many as 40 boys and girls, carefully indoctrinated, rehearsed for the event. Scheduling the baptismal rites so as not to conflict with the program at Mission San Bernardo, for example, the resident Friar at San Juan Bautista invited the married soldiers and their wives for the ceremony. At the church the young candidates 1 ined up, a11 we11groomed and appropriately dressed. The missionary, depending on his ecclesiastical preferences, distributed a list of saints' names as a practical guide, after which the native children selected their godparents from among the military couples. In the actual baptismal rite, the godparents articulated the 
Christian name chosen from the 1ist. At the end of the ceremony for all baptismal candidates, the entire mission pueblo celebrated while the new Christians presented their godparents to the community. 30

The sacrament of baptism, and also the rites of matrimony, confirmation, and extreme unction, deftly intertwined the strands of the social fabric of the Rio Grande settlements. By the winter of 1703,15 of the 30 soldiers assigned to the presidio welcomed their families, causing the work force to construct four additional houses facing the military plaza. At Mission San Juan Bautista the soldiers built a convent of four cells adjoining the church which, together with the church, formed the periphery of an interior yard. At San Bernardo they constructed three cells adjoining the church which became the cloister or inner recess of a convent. At San Francisco Solano the presidial workers only added a nave of double adobe walls to the church. Meanwhile, the natives at the three missions, with military supervision, harvested the corn from the fields, averaging a yield of 300 banegas ( 450 bushels) per mission. 31 For material assistance and other forms of support, the missionary priests reciprocated by attending to the spiritual needs of the presidial families and soldiers. 32

The construction of buildings, the acquisition of material goods and the distribution of foodstuffs required consistent financial disbursement. Although the state absorbed the expenditures of maintaining the frontier garrison, and indirectly the construction program, the necessity of supplying the missions remained an ongoing concern. Normaily the state provided an annual allotment of 450 pesos (called sinodo) to each missionary for personal expenses. In turn, out of this stipend, the missionary procured the requisite supplies and materials for the missions. The friars of Queretaro, prohibited by their rules from administering the funds, hired a layman, called an apostolic syndic, who managed the accounts, both public and private, reviewed the requisitions and distributed the suppiies and provisions. ${ }^{33}$ Quite often, owing to physical distance, bureaucratic inertia and fluctuations in the market place, the materials needed at frontier missions failed to arrive on schedule. The Franciscans at the Rio Grande, cognizant of their particular needs, readily offered suggestions to their college president for resolving delays.

We have conferred among the Reverend Ministers of these missions on the subject of how useful and necessary storehouses are to take care of the souls who are at present being instructed and catechized, and to attract the many souls who come to ask for ministers. We see also that these ministers are in urgent need, and some churches are in not a little poverty...

. . in regard to our needs, Your Reverence, decide on one of these things, either to ask for the full alms [government stipends] which usually are given to the missionaries, or a portion which should be sufficient for the churches and for the needs of the religious, or that Your Reverence assume the obligation to assist apostolically in al1 the needs, and that the missionaries say Mass for the intention of Your Reverence just as the Reverend Fathers do who live in the holy College...34 


\section{THE INITIAL DECADE: PROGRESS AND RECESSION}

During the first decade of operating the Rio Grande missions, the Quereteran friars experienced moderate success and unexpected setbacks. In the Spring of 1705, Diego Ramón, once again assigned to the frontier, personally inspected the missions. He reported to the provincial governor that San Juan Bautista had an aggregate native population of 144, of whom more than half were Christians, including 12 married couples and their offspring. San Bernardo, although with fewer marriages, had a comparable congregation of new Christians and gentiles. 35 Five months later, responding to a gubernatorial request, the friars conducted the first comprehensive inventory of the missions since their founding. Aside from the customary statistics on conversions, instruction, equipment, buildings and agricultural and livestock production (see Tables 1 and 2 at end of article), the report disclosed interesting insights into the human experience. The church of San Juan Bautista, constructed in the form of a cross with two side altars, displayed only one bell in the tower. The resident friar organized several Indian boys into an a capella choir, well rehearsed in standard church hymns, to sing at solemn religious services. In addition to equipment and tools, the report alluded to the ability of Indian women to operate weavers looms for cotton and wool. Reflecting values and customs, while the missionary cultivated vegetables and fruit trees in a garden grove fenced by an adobe wall, the Indians maintained a separate granary for storing items obtained outside of the mission compound. ${ }^{36}$ At Mission San Bernardo, the church was a single-room linear structure with two bells installed in the tower. The missionary, who also had a vegetable garden, exempted eight Indian artisans from training in local government so that they could plow the fields and work in the carpentry shop constructing household accessories (doors, windows, tables, etc.). ${ }^{37}$

Shortly after completion of the inventory, a smallpox epidemic broke out among the mission Indians and devastated the community. The natives of the Rio Grande missions lacked natural resistance to the contagious disease. There was little the friars, like Francisco Hidalgo, could do, except to comfort the sick. Gradually the epidemic subsided, leaving the survivors to face the difficult task of rebuilding. ${ }^{38}$ Altogether, owing to the ravages of the epidemic and other causes, 96 adults and 57 children died at Mission San Juan Bautista, ${ }^{39}$ and 80 natives of all ages at San Bernardo. 40 In the rebuilding process, the friars tacitly accepted a small creek as the line of demarcation between San Juan Bautista and San Bernardo. 41

During subsequent years of development, the missions of the Rio Grande and the adjacent presidio continued to function as complementary agencies of frontier control. In the process of restoration and consolidation, the friars depended upon the military for assistance in recruiting new native converts or in pursuing fugitives. Such close dependence was not without consequence, as disputes frequently arose between missionaries and soldiers regarding priorities, prerogatives and compensations. For the most part, however, there was more harmony than discord among representatives of church and state on the Rio Grande as the region gained importance as a crossroad of empire. In the intervening years, the personnel of the frontier changed. As old-line missionaries, such as 0livares, Espinosa and Hidalgo, retired from the scene, new Franciscan leaders emerged to assume responsibility for guiding the missions through the formative years of the first quarter century. Likewise, the soldiers of the 
presidio established their permanence as settlers in the community. Upon the founding of San Antonio de Béxar in 1718, emulating the model used successfully elsewhere, the Rio Grande passage became an integral component of colonial defense, as demonstrated by the expedition of the Marques de Aguayo in 1720 which definitely secured Spanish territorial claims in Texas.

THE MISSIONS AFTER A QUARTER CENTURY: RENEWAL OF EFFORT

As the first quarter of the 18th century merged with the succeeding period, the viceregal administration of the Marques de Casafuerte, in an attempt to reduce expenditures, directed the military to evaluate the condition of northern frontier defenses. Carrying out the viceregal order between 1724 and 1728, Brigadier General Pedro de Rivera inspected presidios in the arc of the borderlands from Sonora to Texas, including San Juan Bautista. The outcome of Rivera's inspection was the celebrated Reglamento of 1729 which curtailed military commitments in some regions, augmented manpower allocations in other areas and established salary schedules for presidial officers and soldiers. For Presidio San Juan Bautista del Rio Grande, the Reglamento authorized an increase in personnel from 30 to 32 , with an average yearly salary of 300 pesos for enlisted men. 42

Almost parallel to General Rivera's inspection of presidios was Fray Miguel Sevillano de Paredes' visita of the Queretaran missions in Coahuila and Texas. Appointed by the Commissary General of New Spain to conduct a thorough evaluation of all missions in the presidency of the Rio Grande, Fray Sevillano arrived in late summer of 1727 at San Juan Bautista, where he established headquarters for the duration of the inspection. As vice prefect and president of the Rio Grande missions, Sevillano received customary homage from the friars in the community, and he explained to them the purpose and scope of the inspection. Accompanied by an administrative aide, Fray Francisco de Bustamante, the father-president postponed the visita of the nearby missions until after he had inspected the Texas mission of San Antonio de Valero. In mid-October, Fray Sevillano and his assistant returned to the Rio Grande, where in the course of several weeks they conducted a complete examination of the missionary enterprise, ranging from the temporal to the spiritual. Sevillano de Paredes' inspection was a hallmark event in the history of Franciscan missions in the eastern corridor of New Spain; for the first time in a quarter/century of operation, a high-ranking member of the Order actively participated in an onsite assessment of material progress (see Tables 3 and 4 at the end of the article) as well as spiritual development. Mission San Juan Bautista's inventory of buildings and grounds, reflecting a relationship to spiritual advancement, showed significant improvement since the formative years. Although the church still had three altars, all adequately decorated, the belfry now supported four bells. Under construction was a large sacristy, with windows and openings, to replace the original, small dark room adjacent to the church. On one side of the church was the convent which had seven cells, a workshop, a dining hall and kitchen, and a ladder with which to climb to the choir loft. Away from the convent were several enclosures for livestock and a storeroom for safeguarding supplies for missionaries in Texas; behind the storeroom was another enclosure for chickens. A sidewalk led from the convent to a well-kept garden, completely surrounded by an adobe wall, in which friars cultivated figs and other fruit trees and vegetables. The convent was white-washed and, for security, the windows had wooden grills and shutters. 
The mission's pueblo for the natives consisted of 15 flat-roofed houses, plus 17 contemporary adobe huts, and on the periphery were the shanties of the rancheria. The resident friars' objective in the building program, which progressed slowly, was for the entire pueblo to be of permanent flat-roofed houses. Of understandable pride was the stone granary which had a storage capacity of 2,800 bushels of corn.

On the mission's arable fields, after digging an irrigation ditch to obtain water from Arroyo de Castaño, the native workers constructed a smal1 flatroofed house and a granary to store corn. This auxiliary enterprise became necessary for the mission in 1722 when water could not be obtained from other sources. Later, in the upland region, from Nogales Creek, the natives excavated an irrigation canal for 12 or 13 terrestial leagues (approximately 33 miles); in 1727 the canal was not beneficial to the mission fields owing to the paucity of water. At the time of Sevillano Paredes' inspection, the acequia still needed three leagues of construction before reaching San Juan Bautista. As a consequence, the mission operated three farms, all distantly located. At one of the farms, where the acequia from Nogales Creek ended, the native laborers built a flat-roofed house as a convenient shelter in the event of attack by Apache or Toboso marauders who periodically raided the mission herds. 43

Impressive as the record of temporal achievement of San Juan Bautista was in 1727, even more remarkable was the description of spiritual progress which offered insight into the humanist development of the community. Every day in the morning and afternoon the friars instructed the natives in Christian doctrine. Apart from the regular routine, the missionaries also gave instruction to members of the presidial families. In comparing the two groups, the Franciscans admitted that the neo-Christians demonstrated a better understanding of the articles of faith than did the Spaniards. Once a week, on Saturday, the mission Indians marched in procession to the presidio, singing the mysteries of the rosary. At the presidio, the soldiers alternated with the natives in praying the 15 decades of the rosary. Thus, through the medium of prayer and song, the missionaries reinforced the basic tenets of Christianity, gradually persuading the natives to abandon "diabolical chants" of the wilderness. On other occasions, Indian boys and girls joined their elders in singing the Lord's Prayer and the Ave Maria through the streets of the mission pueblo. Besides carefully administering the sacraments to the Indians in good health at San Juan Bautista, the friars also assisted the sick and others near death in spiritual and temporal matters, taking a week's supply of provisions, preparing medicinal remedies and comforting the dying in their final hours. In addition, the resident friar looked after the spiritual needs of the faithful at the presidio, preaching, administering the sacraments and conducting graveside services for the deceased. ${ }^{44}$

Fray Sevillano's inspection of San Bernardo followed the routine established at other missions. The accumulated data, however, revealed interesting variations and differences. For instance, the friars at San Bernardo viewed temporal achievement as the foundation upon which to build a spiritual edifice. Accordingly, they carefully directed the annual increase in livestock production toward securing that foundation. Mission San Bernardo, like San Juan Bautista, began with a seminal herd of 20 head of cattle which, multiplied over the years until the 1727 inventory, and allowing for local consumption and losses due to 
Indian aggression, showed an aggregate of 600 beeves. The inventory for minor livestock also demonstrated significant gains. The friars of San Bernardo, as well as those of San Juan Bautista, separated a small flock of sheep and goats to train the natives in self-discipline and livestock management.

Mission San Bernardo's building program was not as advanced as San Juan Bautista's. The Indian pueblo only had five flat-roofed houses, 16 temporary structures and the nondescript rancherias. The church, with two bells in the tower, served as the convocation center in spiritual guidance. The friars of San Bernardo, cognizant of the fact that the two missions depended on the same available sources of water, directed their workers to excavate an acequia to tap the residue of San Juan Bautista's irrigation canal. Thus, with a minimal supply of water the workers cultivated fields which previously had not been tilled. Even so, the friars admitted in 1727 that progress at San Bernardo, both material and spiritual, reflected advances and setbacks. The decline in agricultural production, principally corn, affected the spiritual domain in that, owing to insufficient harvests, some of the neophytes might be tempted to escape into the hinterland. For the majority of the natives, however, the prospect of having corn for the year, no matter how scanty the yield, was an adequate incentive to remain at the mission. 45

In terms of spiritual development, Fray Sevillano noted that the resident missionary at San Bernardo reserved the mornings and afternoons for catechism lessons. With the aid of a text prepared for religious instruction by a Spanish Jesuit, Father Jerónimo de Ripalda, the missionary realistically tailored the lessons to correspond to the natives' limited understanding of abstractions. Every Saturday the mission Indians congregated at the church to pray the rosary, to sing a few hymns and to recite a long liturgical prayer (letania) in honor of the Blessed Mother. Interestingly, although many Christian Indian men and women at San Bernardo frequented the confessional, very few of them actually received Holy Communion; this was probably due, as Sevillano observed, to their social inexperience or to their constant movement, back and forth, into the wilderness. For that reason, the resident missionary very carefully conducted the doctrinal lessons and administered the sacraments only to the natives who were prepared to receive them. ${ }^{46}$

Equaliy as important as the father-president's assessment of the Rio Grande missions were his observations and recommendations for improving Franciscan endeavors; they disclosed the expectations of the Queretaran leadership regarding the need to establish uniformity of effort. In the area of religious instruction, for example, Fray Sevillano noted that in previous years the Franciscans found it expedient to use a catechism text written by a Jesuit teacher, Father Bartolomé Castaño. When the friars recognized that the Castaño method, effective elsewhere in the borderlands, seemed unsuitable for the native cultures of the Rio Grande, they adopted the next prepared by another Jesuit, Father Ripalda, whose name was synonomous with catechism. Afterwards, the Commissary General of New Spain dispatched multiple copies of the Ripalda text to all Franciscans of the Rio Grande presidency. The missionaries who used Father Ripalda's text reinforced doctrinal lessons with appropriate parables and analogies relating to the abstract concept. 
As much as possible the friars contributed to the temporal development at the missions, such as obtaining a detachment of presidial soldiers to assist the native laborers in the fields and to guard the herds. Every 15 days the missionary authorized the workers to slaughter two steers and to distribute the meat to the natives. On special occasions, such as a wedding, the missionaries permitted the Indians to kill one bullock for the fiesta; in addition, a bullock would be killed for church festivals commemorating Easter, Christmas and Epiphany. Also, depending on the situation, the missionaries allowed the natives to consume the meat of an injured animal. The friars for the most part, however, exercised prudence and frugality in the distribution of foodstuffs, lest the mission herds or granaries be prematurely depleted. Those natives who showed outstanding advancement in self-discipline and leadership in pueblo government were rewarded by the resident missionary with a few goats or sheep; the livestock helped the natives learn the responsibilities of private ownership.

From the corn harvest, the natives received a daily ration at a designated time. Whenever the harvest was bountiful, the friars shared the surplus with the families of presidial soldiers who donated clothing to the Indians. However, if the harvest was limited, the friars restricted the distribution of grain for the sustenance of the natives. During the entire Lenten season, when the consumption of meat was forbidden, the natives received a ration of beans. As an incentive for peaceful coexistence and agricultural productivity, the friars gave to the natives watermelons, muskmelons and squashes. As a further stimulus, depending on the supply available, they even distributed cones of brown sugar (piloncillo).

On a practical level, the extent of the friars' generosity depended on the royal stipend, increased to 440 pesos per missionary per year, with which the college sindico purchased the supplies that the natives ultimately enjoyed--bolts of woolen cloth (sayal), blue woolen cloth (palmilla) or thick flannel (bayeta), plowshares, hoes, axes, tobacco, glass beads and rosaries. Out of this stipend the missionaries paid for the services of a blacksmith to repair the tools the laborers used in the fields. Finally, the sindico also procured expendable and other supplies the missionary needed for the church, as well as a few personal items such as chocolate, soap, salt and piloncillo. ${ }^{47}$

\section{CLASH OF CHURCH AND STATE}

Toward the end of the third decade of the 18th century, the cooperation between church and state on the Rio Grande, which characterized the earlier years, began to show signs of strain as dominant personalities asserted their convictions on different issues. The rigidity with which Brigadier General Pedro de Rivera carried out the government's instructions to reduce expenditures in frontier defenses, for instance, conflicted with Fray Miguel Sevillano de Parades' sense of priorities. With respect to Presidio San Juan Bautista del. Rio Grande, Rivera criticized the traditional assignment of a two-man escolta to each of the missions in the vicinity to perform managerial duties. Since the friars considered such supervision essential to the welfare of the missions, the general suggested an alternative of hiring civilian settlers to fulfill that need. The soldiers, he felt, should be restored to the presidio where they could function in a strict 
military capacity as he envisioned in his Reglamento. 48 The father-president, on the other hand, rejected the military's argument that the responsibilities of the church and state in the frontier were mutually exclusive spheres of action. Allowing for the partisanship in Sevillano's critique, which he wrote as a counterweight to offset Rivera's proposals, the friar's commentary regarding the interdependence of missionaries and soldiers contained generalizations applicable to the history of the region for the entire 18th century. Concentrating on the tendency of the natives to flee from the missions and on the necessity of military assistance in retrieving them from the wilderness, Fray Sevillano explained:

It does not seem convenient to abandon the missions, leaving the Indians to die without benefit of the sacraments in the event of an emergency. This lack of encouragement at this time... . is the reason why [the preaching of] the Gospel has stopped momentarily in these parts. Many missions could be founded with which to save many souls for God, and pueblos [could be founded] for the splendor of the Royal Crown. The gentiles in these environs are countless; and they are not so reluctant to improve themselves once they recognize the gentle power of the military with which they will be invited to live as rational beings. Neither the gentiles nor the Christian fugitives who are living in the woods can attest the Catholic faith. . . living as they are without knowledge of God, and without submission to the King, each one acting at will in the freedom of the wilderness. It is not a difficult task to bring them into the pueblo, those who have fled, as well as those who have never been [in a mission] as one can tell just by looking at them. The Christian fugitives, upon seeing that they were pursued to return to the mission, can be grouped in one large section [of the mission] and the gentiles can be confined to the rancherias [on the periphery]. This grouping can be done by the soldiers who take them out of the woods and escort them to their pueblos. In fact the soldiers actually do this of their own accord, as was the case in the uprising at San Juan Bautista and San Bernardo when only sixteen men and a religious [leader] were sufficient to bring the fugitives out of a large rancheria inhabited by five hundred barbarians [bárbaros], armed with bows and arrows, and return them to the missions These missions would be much more advanced if the military had maintained its level of assistance as in earlier years. . .49

The church and state controversy increased in intensity at the Rio Grande when General Rivera publicly announced at the presidio that soldiers were not to be used for pursuing Indian fugitives from the missions. As if to aggravate the situation further, Rivera challenged the padres to grab their walking-sticks and crucifixes and go after the fugitives alone. 50 Actual1y, the general did not oppose the missionaries' goals of conversion. However, given the penchant to reduce expenditures, Rivera, in his mind at least, separated the temporal obligations of the state from those of the church. A timely reminder from the viceroy to the general, received at Presidio San Juan Bautista on December 29 , 1727, ameliorated the tension. 
By whatever extraordinary ways and means possible Iwrote Viceroy Casafuerte], His Majesty has ordered the encouragement and ass istance for the conversion, settlement, and instruction of the Indians, particularly of the regions [parajes] and Provinces in which recent converts now live and where Indians are presently undergoing [religious] conversion. There should be neither neglect nor carelessness towards these Indians since it is $H$ is Royal wish that they should be congregated and instructed in Our Holy Faith, such is the extent to which the Royal Treasury is making considerable expenditures for the subsistence of many missionaries in different parts [of the frontier], especially in Nayarit, Nueva Vizcaya, Nuevo Mexico, Nuevo Reyno de Leon, and Texas. I forward this directive in the name of His Majesty for whom I ask and implore all of the Reverend Father Superiors of the missions to exert their devotion, charity, and fervor in the conversion, settlement, and instruction of the Indians with the care and commitment which $H$ is Majesty has ordered, thus bringing and educating them in our Religion. This [goal] should be achieved with the gentleness and affection prescribed by laws and ordinances for those [persons] engaged in the Holy Ministry. The missionaries should know the language of the Indian tribe or tribes with whom they are working, otherwise, falling behind in their work, they will become discouraged in the Ministry of Our Holy Faith. [And for the Indians] to achieve salvation, they should be instructed in learning the Castilian language, according to their maturity and the limit of their capacity. The Reverend Missionary Father should apply whatever methods are appropriate for the welfare [of the natives] to fulfill the wish of the King Our Lord. I expect the Reverend Fathers to cooperate fully with the intent of $\mathrm{His}$ Majesty's wish... 51

Adamantine as the positions of the general and the friar appeared to some observers, the union of church and state on the Rio Grande survived the conflict of two strong-willed personalities.. When the viceregal government implemented Rivera's recommendations in the Reglamento of 1729, the eastern frontier of Texas sustained the impact more than the Rio Grande settlements. Following the general's suggestions, the government suppressed one of the east Texas presidios, causing the Queretaran Franciscans in 1731 to transfer three of their missions to the banks of the San Antonio River.52 On several occasions between 1731 and 1737, during the presidency of Fray Jose Gonzales, the Rio Grande missions, mainly San Juan Bautista, furnished livestock and grain to the transferred missions in San Antonio. For instance, to sustain the Queretaran missions in their first year of operation, the friars of San Juan Bautista sent 1,200 bushels of corn and a herd of 250 cattle. 53

\section{PRESIDIAL SETTLERS}

The willingness of the Rio Grande friars to support their fellow Queretarans in Texas with provisions revealed the close-knit administrative network of Franciscan missionary effort in the Spanish borderlands and the temporal capabilities of San Juan Bautista and San Bernardo, secured in part by the proximity of the presidio. Notwithstanding differences of opinion by high-ranking generals and father-presidents, the physical presence of the military provided a veneer of safety to the 
Rio Grande which attracted civilian settlers. A distinguished borderlands scholar., Max Moorhead, wrote: "Perhaps the most significant historical aspect of the frontier presidio was its role as a nucleus for civilian settlement, for many of the towns and cities of northern Mexico and southwestern United States emerged from presidial beginnings."54 By 1732 Presidio San Juan Bautista, as revealed in a census requested by church authorities, had a non-military population of 58 families, some of whom had servants. The significance of these 215 civilian settlers was that they outnumbered the 32 presidial soldiers and their families. 55

\section{MISSION LAND GRANTS: THE ACT OF POSSESSION}

The aggregation of civilian settlers to the number of military families at Presidio San Juan Bautista inevitably increased the necessity of establishing priorities with regard to the use of available water. In fact, because the water of a lake in the vicinity was unsafe for human consumption, the friars of San Bernardo petitioned their college president, Fray Gabriel de Guevara, to appeal to the viceroy-archbishop, Juan Antonio Vizarrón, to support the Franciscan's claim to the unused water source of abandoned Mission San Ildefonso, located 14 leagues (approximately 36 miles) northwest of the crossroad. The viceroy, who manifested special interest in the success of the Rio Grande missions, responded by directing the governor of Coahuila, Clemente de la Garza Falcon, to assign the land and the water to the natives who resided at Mission San Bernardo. On the morning of Thursday, Apri1 24, 1738, Governor de la Garza Falcon led a mixed group of followers out of the presidio eastward into the countryside to execute the formal act of possession. Included in the group were Captain José de Eça y Músquiz, commandant of the presidio, Fray Alonso Giraldo de Terreros, father-president of the Rio Grande missions, Nicolás Ximénez and Pedro de Orozco, witnesses for the state, and the governor and alcalde of the pueb 10 who represented the dominant native cultures (Chaguanes and Pachaches) at the missions. Arriving at a willow grove, the group turned northward around the edge of a marsh (Ciénaga de las Nogales), from which Mission San Juan Bautista obtained water, and proceeded across a green meadow until it reached a natural spring named in honor of San Bernardo. The governor, assisted by Fray Terreros, took the pueblo leaders by the hand and, in a loud voice, declared that the king had granted to the mission Indians the land and resources which would be administered by the Franciscans. To symbolize the act of possession the representatives of church and state walked with the recipients over the 1and, filling a container with water and sprinkling it around the periphery, pulling up tufts of grass and tossing them into the wind, scooping up soil and scattering it in four directions, and picking up rocks and throwing them into the distance. Then, to familiarize the witnesses with the outer limits of the grant, the governor led the group northward again, past a mound infested with ticks (Mota de Las Garrapatas), to the ruins of San Ildefonso. Traveling a narrow pathway to the junction of two creeks (Escondido and San Antonio), the governor's party followed the course of the tributary to the Rio Grande, then south along the riverbank to the main crossing--Paso de Francis--which was recognized as a principal line of demarcation for the lands of Mission San Bernardo. Proceeding westward, the governor's retinue ended the journey at the bridge traversing the irrigation ditch of Mission San Juan Bautista, which also conveyed water to the families of the presidio. Cognizant of the fact that the friars of San Juan Bautista shared the mission's riparian resources with the settlers at the presidio, 
Governor De la Garza Falcón incorporated a couple of novelties into the ceremony. to confirm the Indian's land grant. For domestic flair, the mission Indians, in addition to the standard procedure, opened and closed the church doors and rang the bel1s in the tower. ${ }^{56}$ As a concomitant aspect of the acts of possession in 1738, the governor asked the friars for a census of the mission populations. Interestingly, the census reports disclosed that San Bernardo, with a congregation of 563 natives, exceeded San Juan Bautista's population by nearly two to one (see Table 5 at the end of the article). 57

Several factors accounted for the sizeable increase of native inhabitants at Mission San Bernardo in the late 1730s. First was the presence of a dynamic Franciscan father-president, Fray Alonso Giraldo de Terreros, who personified a new generation of missionary frontiersmen trained at the college of Santa Cruz de Querétaro; second was the concentration of families mainly from two tribal groups which undoubtedly attracted gentiles of similar ethnicity to the mission; third was the relative security of the southern interior zones of Coahuila which shored up the riverfront missions; and finally there was the collective experience of four decades of which the father-president was certainly aware in making San Bernardo an exemplary center of spiritual conversion. In retrospect, the significant increase of native inhabitants at San Bernardo, compounding the human demand for distribution of natural resources, in all probability influenced viceregal and provincial authorities to delineate the land grants of the two missions in 1738 .

\section{FRIAR TERREROS AND A NEW GENERATION OF FRONTIERSMEN}

During Fray Terreros' active presidency, the missionaries, accompanied only by acculturated native interpreters, frequently journeyed into the wilderness to recruit neophytes. Since a basic step in the process was to assemble natives within the mission compound, the friar, through the interpreter, offered food and clothing, assuring the recipients that a Supreme Being had endowed their bodies with a soul. As a prime example of conversion, the interpreter, carefully guided by the friar, gradually broached the subject of living at the mission, emphasizing the material benefits of an ample supply of maiz and fresh meat, as well as the annual distribution of clothing and colorful ribbons sent from the distant college of Santa Cruz de Querétaro. The friars, said the interpreter, also furnished farming tools and household utensils such as metates, kettles and cooking griddles (comales).

The comparatively high concentration of Indians at both San Bernardo and San Juan Bautista in the early 1740s renewed the perennial problem of military support for internal development and external protection at the missions. In the immediate aftermath of General Rivera's inspection, which culminated in the Reglamento of 1729, the commanding officer of Presidio San Juan Bautista suspended the escalta of two soldiers per mission. By the mid-1730s, however, the realities of rising warfare by native aggressors and the friars' program of determined evangelization convinced the presidial commander, no doubt with the consent of the governor, to suggest a compromise version of the escolta, namely assigning one soldier at each mission. Encouraged by the attention they enjoyed at the viceregal court of Archbishop Vizarron, as well as at the gubenatorial office of Coahuila, the Fransicans of the Rio Grande, led by Fray Terreros, succeeded in their effort to obtain 
a reevaluation of the escolta system. For several days, beginning on November 9, 1740, Captaîn Josê Hernândez summoned friars, soldiers and senior settlers to the presidio to testify on conditions at the nearby missions. Following a standard procedure of interrogation, each witness, as a gesture of respect and veracity, made the Sign of the Cross and responded to three specific questions regarding the missions' native population, internal and external security, and the conduct of the missionaries' religious obligations. ${ }^{5}$ Typical of the witnesses was 62-year-old Jose Flores who testified that the aggregate population of San Juan Bautista was 436 Christian Indians and gentiles and that of San Bernardo was 460. In Flores' opinion, because of native hostilities, some of which transpired almost daily, the escolta of two soliders at each mission, as in the past, was essential for their continued development, one to supervise and protect workers in the fields, and the other to escort and assist the friars in the wilderness in pursuit of fugitives. As an indication of the missionaries' diligence in religious duties, Flores acknowledged he had heard of at least 35 new baptisms, 15 of which had occurred lately. 60 With respect to the same baptisms, another witness; Josê Menchaca, affirmed he had stood as godfather in numerous ceremonies. 61 The final witness, 60-year-old Francisco Salinas, declared that the present system of a one-man escolta was an inadequate safeguard for the missions. As demonstrated in the recent raids, Salinas continued, the soldier left the missionaries exposed to danger as he rode to the presidio for reinforcements. ${ }^{62}$ On November 12, 1740, Captain Hernández concluded the hearings, signed the affidavits, which he considered "ample and sufficient," and forwarded his recommendation for the restoration of the two-man escolta for the missions. 63

The soldiers' presence notwithstanding, native marauders, mostly Apaches, continued raiding the missions, inflicting untold terror and sorrow among the inhabitants. Symptomatic of the discouragement the attacks created even within the religious community was a report from Fray Francisco Antonio Lopéz to the father-guardian of Santa Cruz de Querétaro. As president of the Rio Grande missions and resident minister at San Bernardo in the late 1740s, Friar López described to his superior the disappointments of the frontier experience.

In such circumstances, if the enemy attacks, how can one excuse the bitter and sorrowful setbacks to the missions, to the settlers, ranchers, and the presidials, to their persons, families, and welfare? Is it not possible that [Indian aggression] can be deterred occasionally without soldiers? In these cases I find myself completely regretful for having left the unity, silence, and security of my College. I will reiterate to you incidents which have occurred at this time, without referring to other deaths, destruction of horses and other livestock, and continuous terror . . . Last year of forty-eight [1748], on the 26th day of January, a large number of warriors came to this Mission of San Bernardo, at the time that [our] Indians were harvesting their corn. They killed two, [and] wounded with arrows the soldier in charge of the workcrew. I was alone, about to reach the farmland, when they chased me for a long distance. During this same year, they attacked the ranch belonging to a widow and in plain sight killed her son and a shepherd, and with lances and arrows destroyed the majority of the herd. In all these occurrences, the aggressors left without punishment because there were no soldiers. And even if there were only a few, the enemy is so numerous that the multitude 
and the fear from the danger makes us retreat immediately . . . What has been said can be proven better with the following case which occurred on Saturday, July 5th of the present year 1749 at the banks of the Rio Grande. Returning from San Antonio to his college of Our Lady of Guadalupe of Zacatecas was the Reverend Father Fray Francisco Xavier de Silva, minister of a new settlement located near the Nueces River. Just before reaching the Rio Grande, at a distance of two leagues, Apache marauders attacked the travelers who were unable to defend themselves. They killed the Religious [the friar] with such cruelty that after having split his head in the form of a cross, they gave him many blows with lances, arrows, and knives. They literally skinned his back from his shoulders to his legs. Those bloody wolves did not execute with such carnalistic acts the eight other companions who also died, four of whom were soldiers. The following Sunday, two Indians from [Mission] Concepcion found the bodily remains, giving immediate notice to this Presidio. All of the soldiers went out (they were only five), accompanied by some settlers and some mission Indians. They buried the maimed bodies and brought the body of the Religious with two other bodies that were not as mutilated. There was neither demonstration nor pursuit because they were few in number and found themselves overwhelmed by fear and terrified by the horror . . .64

Assurediy the loss of human life, especially the martyrdom of a Franciscan, temporarily reduced the momentum of evangelization. Nevertheless, once the initial shock subsided, the practical considerations of advancing the mission process required constant attention. Friar López' account of frequent desertions offered an interesting commentary on native behavior at the Rio Grande.

Experience has taught us [he wrote] that the motivating cause of these frequent desertions can be nothing else than the desire which is natural to youth; that is, from the moment of their birth upon the land they become so attached to it that they cannot forget it. At sunrise, and before everything else, they gaze upon their distant land. This longing has its source of inspiration in the persuasions of their own companions, or from members of other tribal groups who also persuade them, and at the same time by that attractive allurement which they always leave behind in the woods . . . Collectively and associated jointly with their own idleness, apprehension, appetite for laziness, and vagabondness induce them more to run away.

To questions and reprimands about their culpable fickleness, they allege convenient, original excuses: They are accustomed to excusing themselves by saying that they were scolded by their father-in-1aw; that their wives were being whipped; that their relatives called them; that others came to invite them to hunt buffalo and pick cactus pears which were abundant. They also complain that there is too much work and prayer; that $i 17$ ness killed their relatives and many of their tribal folk and that they run away from the mission to avoid the same fate; that they wish to die at the place where the Apaches killed their parents; and other excuses of the same tenor. I have not heard them say that they lack food and clothing, because I assure you in all honesty that I have not seen in any Pueblo anyone who is better clothed, cherished or assisted in everything, in sickness and health, as is generally known. . 65 
A practical index that yerified Friar López assertion regarding the quality of welfare the natives enjoyed was the account ledger of Mission San Juan Bautista for 1749. The checklist of merchandise, requisitioned or received from the College of Santa Cruz, included cooking utensils, ceramic ware, food products, confection, cutlery, hardware, textiles, dry goods, wearing apparel, novelties, small accessories, religious goods and incidentals. 66

\section{THE CROSSROAD AT MID-CENTURY}

As the 18th century approached the middle period, the Rio Grande missions and the neighboring presidio symbolized the old-line settlements whose inhabitants showed a remarkable tenacity for enduring the challenges of frontier living. During those pivotal years, important changes occurred in Franciscan leadership and objectives at the crossroad which affected the course of empire in the borderlands. Within the limits of their resources, the Rio Grande settlements, both church and state, supported moderate expansion in several directions. Starting in 1746, the Queretaran frairs, using San Juan Bautista as the main base of material assistance, established the San Xavier missions for. Apaches on the San Gabriel River in north-central Texas; the missions floundered for three years without achieving a modicum of success. In 1749 the missionaries terminated the San Xavier project and concentrated on other undertakings.67 In the 1750s, José de Escandón's successful widespread colonization of Nuevo Santander in the Lower Rio Grande Valley was a significant factor that contributed to a realignment of priorities on the northeastern fringe of Coahuila. Following the termination of the San Xavier missions, the Queretaran friars of the Rio Grande, during the college presidency of Fray Terreros, seriously contemplated the prospect of transferring San Juan Bautista and San Bernardo to the diocesan clergy in order to devote more attention to the conversion of Lipan Apaches in Texas. 68 The implications of the transfer proposal were clear. From the vantage point of the church, the Rio Grande missions, after a half-century of operation, had achieved a respectable level of material development to warrant distribution of land, Tivestock and equipment to the Christian Indians, with which they might earn a livelihood. More central to the issue was the Franciscans' conviction that the present generation of native converts, their human imperfections to the contrary, displayed sufficient maturity to enable them to perform responsibly as citizens of the state and as members of a diocesan parish. The implication of the transfer suggestion which obviously prevailed was that the state, for reasons of imperial integrity, viewed the Rio Grande missions as indispensable components of a larger unit of frontier defense that should be maintained indefinitely.

The return of Friar Terreros as president of the Rio Grande missions in 1751 signified a notable change in apostolic spirit and focus. Both San Juan Bautista and San Bernardo, at least to Fray Terreros, stood as active historical monuments of an earlier era. As an individual whose 01d World heritage closely identified with the missionary movement of New Spain, Terreros, known "for his living faith and.. . zeal," strongly advocated expansion, through missions and presidios, into the northern frontier. 69 of special benefit to Friar Terreros' plans, a clash of personalities in Texas, stemming from differences of opinion between church and state officials bearing upon the defunct San Xavier project, resulted in a change of administration. The college guardian of Santa Cruz de Querétaro, anxious to restore harmony in frontier Texas, early in 1752 directed 
Fray Terreros to leave Father Miguel Plácido de Alaña temporarily in charge of San Juan Bautista as he switched positiöns with the president of the San Antonio missions. Aware of the criticism that accrued to the administrative change, and at the same time desiring to mollify injured sensitivities of an experienced missionary leader, the guardian interpreted the assignment of Fray Mariano Francisco de los Dolores y Viana to the presidency of the Rio Grande as a promotion. 70

In 1756, 29 years after the famous visita of Sevillano Paredes, the Franciscans of the Rio Grande, anticipating a possible, though highly unlikely, transfer of their missions to the diocesan clergy, prepared for another full-fledged inspection, this one conducted by Fray Francisco Xavier Ortiz. At San Juan Bautista, showing a continuing interdependence of frontier institutions, the visitador comisario, in addition to the regular mission records, found a separate set of books for the soldiers and settlers of the presidio. Illustrative of the material progress achieved since the 1727 inspection, the church decorations now included carved statues and religious pictures in gilded frames. Among the furnishings were wooden pews: kneelers, confessionals, pulpits and shelves. For the roof and floor of the church, the workers, recruited undoubtedly from the nearby presidio, utilized heavy cypress beams and planks. Indicative of the quality of the workmanship, the church tower supported six bel1s, the largest of which weighed nearly 265 pounds. Another mark of progress was the whitewashed convent, of stone and mortar with a sturdy roof of long beams and boards, which contained eight cells, two of which were living quarters for the resident missionaries and the others served as guest rooms and workshops. Three arches of rubble masonry distinguished the main office, which was similarly roofed with long beams and planks and had a well-built door and entrance bel1. Another innovation since the previous visita. was the tapestry shop, where Indian artisans wove and twilled wool and cotton; it measured 30 varas $10 n g$ and had walls of stone and mortar. Constructed of the same material was the corn granary, which had 10 windows for ventilation and rubblework pillars in the center supporting a roof of cypress beams. 71

In contrast to San Juan Bautista's measure of material achievement, Mission San Bernardo showed evidence of both deterioration and renovation. The missionaries rarely used the original church, almost in ruins, for religious services. Instead, while construction progressed on a new mission center, they congregated the natives for instruction in a temporary adobe structure with a thatched roof. For the new center, complete with church, convent and Indian dwellings, the friars selected a more suitable location about two miles closer to the older settlements of the river corssroad. The convent, constructed of stone with mesquite beams, included a bedroom for the missionaries, an office and four small workshops. Among the larger buildings were two granaries; the first, measuring 29 varas in length with a beam-and-plank roof, was for equipment, and the other, under construction, was for grain. Within the crescent-shaped compound of the mission were beam-covered walkways supported by mesquite posts. Adjacent to the new mission were the farm lands, where the friars of earlier years had initially located them, with sufficient irrigation water. The schedule of construction in 1756 listed the Indian pueblo for the next phase of work. 72 


\section{EXPANSION FROM THE RIO GRANDE}

Frontier leaders of the Rio Grande in the mid-1750s capitalized upon the material progress of San Juan Bautista and San Bernardo to respond to the Apache threat from Texas by establishing an experimental outpost, Mission San Lorenzo, for their conversion at a site 18 leagues west of San. Juan Bautista (approximately 47 miles), near the Villa San Fernando de Austria. For about 10 months, under the guidance of Fray Martín Garcîa, San Lorenzo showed prospects of moderate gains. Then, in October 1755, the Apaches rebelled against the discipline of the mission way of life. After looting the church and destroying the temporary structures, they fled into the northcentral hinterland of Texas. ${ }^{73}$ The failure of San Lorenzo convinced church and state officials, particularly Fray Alonso Giraldo de Terreros, that a more effective method to contain the Apache threat was to establish missions in an environment indigenous to their culture within the farthest confines of the Province of Coahuila. The result, thanks to the philanthropy of Fray Terreros' cousin, Don Pedro Romero de Terreros, later Count of Regla, was an elaborate plan of northern development beyond the Rio Grande toward the San Saba River. In December 1756, the vanguard of expansion--Fray Terreros, personifying the church, and Colonel Diego Ortiz Parrilla, symbolizing the state--paused at Mission San Juan Bautista to obtain equipment, supplies and seminal 1ivestock for the new enterprise. In the spring of 1757, Fray Terreros, in honor of the name of his college, founded Mission Santa Cruz de San Sabá, while Colonel Parrilla, in deference to the incumbent viceroy who authorized the project, established Presidio San Luis de 1as Amarillas. ${ }^{74}$ The Spaniards' expansion into the north with missions for Apaches precipitated unremitting retaliatory warfare by Comanches which culminated in March 1758 in the destruction of Mission Santa Cruz de San Sabá. Among the casualties were six soldiers and two missionaries, including the redoubtable Fray Alonso Giraldo de Terreros. The disaster at San Sabá, a definite turning point in Spanish imperial policy in the northeastern borderlands, 75 reestablished the geopolitical significance of the church and state complex of the Rio Grande, as the 1 ine of Coahuila's frontier contracted in the 1750 s.

During the succeeding decade, Mission San Bernardo superseded San Juan Bautista as headquarters of the Rio Grande presidency. In 1761 the governor of Coahuila, Jacinto Barrios Y Jáuregui, personally reviewed operations at the Rio Grande. The census of San Bernardo, as a barometer of apostolic activity, showed only 370 natives participating in the religious instructional program of Friars Diego Jiménez and Joaquín Baños. ${ }^{76}$ An explanation for the decline in mission population was that the successor father-president, symbolically picking up the mantle of Fray Terreros, broadened the role and scope of the Rio Grande to include new missions for Lipan Apaches in the upland headwaters region of the Rio Nueces. Early in 1762, with protection furnished by a contingent of soldiers from Presidio San Luis de las Amarillas, whose commander favored the Rio Nueces project, Friar Jiménez founded two missions, Nuestra Señora de las Candelaria and San Lorenzo de la Santa Cruz (the nomenclature of the latter inspired by an earlier effort elsewhere), both of which assumed the geographic identity the Spaniards gave to the area--LOs Cañones or, singularly, El Cañon. 77 Although during their brief existence each of the Cañón missions succeeded in congregating more than 400 Lipan Apaches, the lack of financial assistance from the government, coupled with the natives' resistance to the planned activities of work and prayer, foretold the eventual descent of a gallant effort. Before the end of the 1760s, a combination of circumstances beyond their control compelled the Franciscans to terminate the Apache missions of the upper Nueces River. 78 


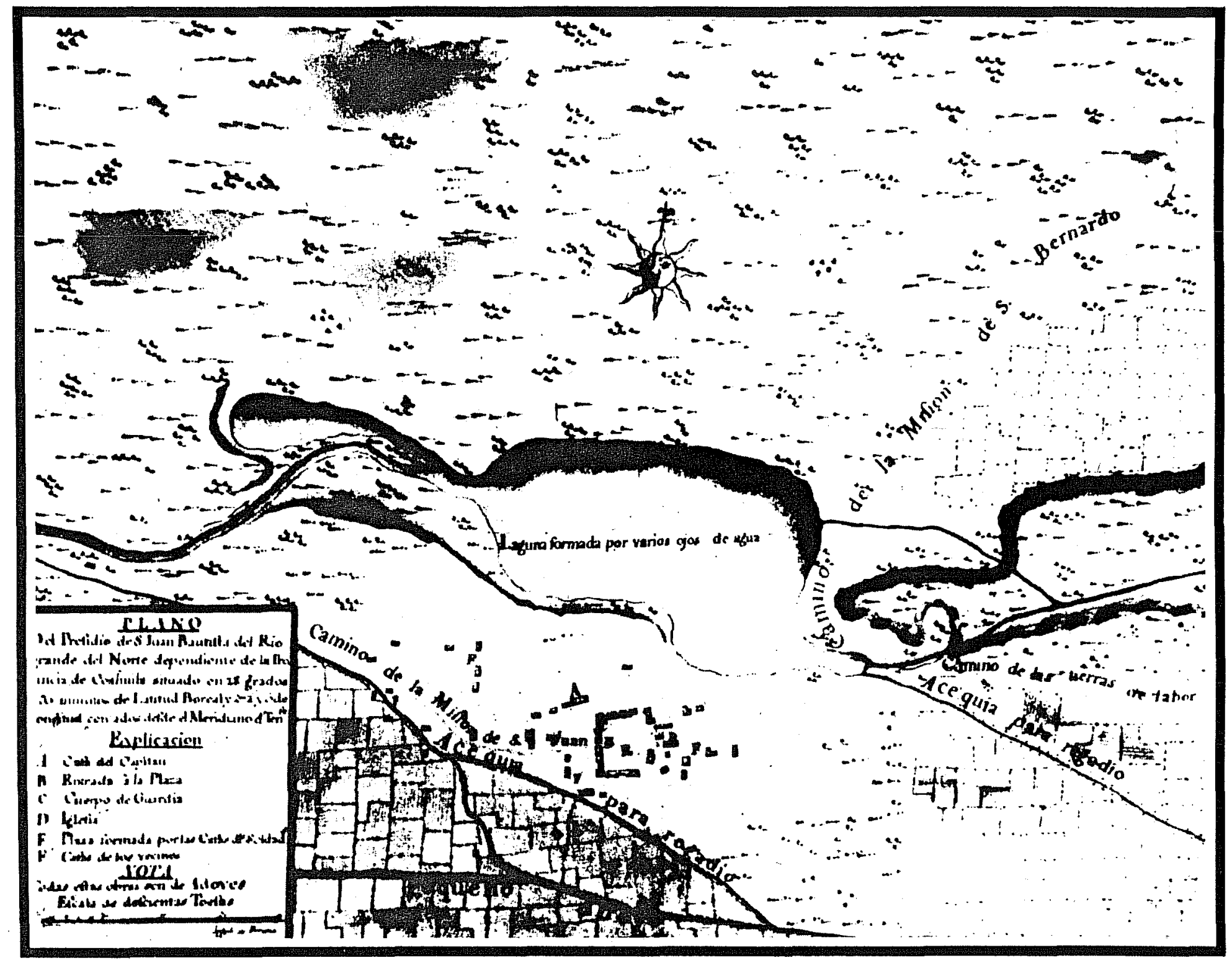

Figure 2. Map of Presidio San Juan Bautista in 1767. By Joseph de Urretia; Courtesy of Luis Navarro Garcia, Don. José de Gálvez y la Comandancia General en las Provincias Internas del Norte de Neuva España. 
THE BOURBON REFORMS

In the second half of the 18th century, the Spanish monarchical state and its colonial possessions underwent a series of fundamental changes known collectively as the Bourbon-Reforms. Designed to strengthen imperial defenses, to modernize the bureaucracy, to revitalize cormercial resources and to increase government revenues, the Bourbon Reforms reached the height of implementation in New Spain in the 1760s and 1770s following territorial readjustments in North America. At the conclusion of the French and Indian War (in Europe called the Seven Years' War) in 1763, Spain received al1 of France's mainland possessions west of the Mississippi River in compensation for colonial losses elsewhere. In the context of North American boundary arrangements, the geopolitical significance of the borderlands became apparent when the Marqués de Rubi inspected the cordon of presidios from 1766 to 1768 . Notwithstanding the importance of safeguarding the Spanish empire in the north, another event of grave consequences for the borderlands, interpreted by supporters of the Bourbon state as a reform, was the sudden expulsion of the Jesuits from New Spain in 1767.79

Reminiscent of another inspection in the 1720s, but with greater pomp and protocol, the Marques de Rubi, with an entourage of technical assistants, visited every presidio in the arc of the borderlands from Sonora to Texas. The outcome of Rubi's evaluation was a realignment of presidial defenses guided by an updated reform Reglamento of 1772 . With regard to the eastern corridor, Spanish control of the Trans-Mississippi West vitiated the necessity of maintaining a political-military outpost in the piney woods of Los Adaes. Hence, San Antonio de Béxar, eminently more secure because of its missions, presidio and civil settlement, emerged as the provincial capital.80 At the middle Rio Grande frontier of Coahuila, the Marqués de Rubi, although not completely satisfied with the condition of military preparedness, allowed the presidio to remain at its present location but increased the manpower level to 57 plus 10 Indian scouts. Another local change occurred in the presidio's name. Deleting the ecclesiastical reference to San Juan Bautista, the military charts henceforth listed the garrison simply as Presidio del Rio Grande del Norte. Of wide-ranging significance, the 1772 Reglamento precipitated a number of reforms in military administration for the borderlands, the most important of which evolved in 1776 with the Commandancy General of the Interior Provinces to deal more effectively with the aggression of Comanches, Apaches and other hostiles, and with potential foriegn encroachment. For the presidio and missions of Coahuila at the Rio Grande, the creation of an independent frontier military bureaucracy signified that the center of accountability shifted from the viceregal court in the south to the headquarters of the commandant general in the north: 81

The reasons for the expulsion of the Society of Jesus from Spanish America in 1767, unquestionabiy complex owing to the Jesuits' global organization, stemmed from multiple causes that gained momentum in the 18th century's period of Enlightenment. Paramount among the causes of the expulsion were the Jesuits' conservative philosophy in matters of faith and morals; their arrogant efficiency in temporal affairs; the criticism they aroused from both church and state officials for their apparent intransigence in the administration of missions; their wel1-publicized allegiance to the Papacy in a time of rising nationalism; their celebrated reputation in the field of elitist education; and the designs of enlightened governments to seize the corporate wealth of the Jesuits. ${ }^{82}$ For Spanish America there was the additional complaint of the Jesuits' recruitment of non-Spaniards for assignment to missionary frontiers. ${ }^{83}$ 
Aside from an emotional outcry among the Jesuits' loyal supporters in New Spain, the immediate effect of the expulsion upon the borderlands was an acute manpower shortage in the missionary field. To fill the vacuum created by the expulsion, the viceregal bureaucracy in 1768 issued an appeal to old-Tine missionaries, especially the Franciscans of Santa Cruz de Querétaro, to assume responsibility for the former Jesuit lands in Sinaloa, Sonora, Arizona and Baja California.84 Early in 1772, in the eastern corridor, the Queretaran friars, after intensive self-study, announced their decision to transfer the administration of their missions in Coahuila and Texas to the Franciscan Province of Jalisco (Guadalajara) and the Apostolic College of Zacatecas, respectively. 85

\section{TRANSITION: QUERETARAN WITHDRAWAL AND JALISCAN SUCCESSION}

The Queretarans' decision to give up their missions to fellow Franciscans of Guadalajara created a mild reaction among residents of the Rio Grande crossroad. The presidial commander, Captain Vicente Rodriguez, expressed concern that the transfer would cause the neophytes to abandon the missions altogether. Soldiers and civilian settlers at the presidio forwarded a petition to the viceroy protesting the proposed transfer, citing among various reasons the likelihood that mission fugitives, forming alliances with hostile natives, would lead aggressors to the riverfront community in retaliation for actual or imagined offenses against them. Assured by the guardian of Santa Cruz de Querétaro that Presidio Rio Grande del Norte had adequate forces to prevent widespread desertion, the viceroy directed Governor Jacobo de Ugarte of Coahuila to issue appropriate orders to Captain Rodriguez, as the agent of the state, to begin the formal transfer of San Juan Bautista and San Bernardo to the Franciscan delegate of the Province of Guadalajara. Accordingly, in late November 1772, Captain Rodriguez notified Fray Diego Jimenez, father-president of the Queretaran missions of Coahuila and Texas, that Fray Luis de Lizarrana of Guadalajara was prepared to accept the transfer of the two Rio Grande missions:

With proper observance of protocol, Captain Rodriguez, accompanied by a complement of witnesses, commenced the transfer of November 27 with a thorough inventory of Mission San Juan Bautista. Aside from the buildings, workshops, living quarters, equipment, livestock and agricultural produce, the two categories of the inventory which contrasted the spiritual and the temporal were the headcount of 96 male and 73 female -Indians and the check 1 ist of 1 inens, ornaments, vestments and sacred vessels in the church. 87 The contrast became apparent in the description of the church's interior furnishings.

MAIN ALTAR. This comprises mostly of oil paintings with corresponding hooks for the following religious images: High at the top is an oval frame of two varas in length of Our Lady of Light with its gilded frame and border. [Adjacent to it are] two semi-round mirrors [espejos de luna] about a vara in diameter, with gilded frames embedded into the wall. There is a carved statue of St. John the Baptist, about two varas in height and ornamented. There is another carved statue of the Immaculate Conception, about three-fourths of a vara in height appropriately dressed with an imperial crown on the head and a silver half-moon at its feet, and other adornments of pearls and trinkets.. . The [Background of the] shrines of the Immaculate Conception and of the [mission's] titular saint are covered with purple satin, and on each side are six tapestries of blue 
and red satin. On the Epistle side of the altar is a carved statue of St. Anthony, and on the Gospel side is a carved statue of St. Francis, both larger than a vara in height and oil painted, as are their pedestals. The tabernacle [on the altar] is carved, with gilded columns, cornices, and spires, for the abode of the Blessed Sacrament, with its door, lock and key. The interior of the tabernacle has an altar stone [ara] and corporals, and is covered with a satin veil from Toledo. The door of the tabernacle is decorated with a silver cross, flowers, and an image of Our Lady of Bethlehem with its crystal glass. On both sides of the tabernacle are two candleholders decorated and 1 ined with Indianilla [cloth imported from India] which serve to distribute lights on solemn days of observance. Above the tabernacle on the Gospel side is a statue of the Christ Child, of a half vara in height, on a gilded pedestal, with a silver wreath and [silver-threaded] fabric. [On the opposite] Epistle side is a statue of Saint Francis of the same height on a gilded pedestal.

The altar table, constructed of cypress wood, has its altar stone, double altar linen, dust cover of Indianilla material, crucifix, candlesticks, and prayer cards. It also has a credence card with a plush frontal, two gilded pedestals for the processional candlesticks. On the Gospel side is a niche with a satin-covered base, upon which is a chest with a door, metal lock plate and key, and satin veil, that serves as a repository for the holy oils. Lined in green velvet, the chest contains four vessels, metal lock plate and key, and silver corner-plates. There is another small brass box with three silver vessels. There is a table, reinforced with walnut wood, that serves as a communion altar covered with Rouen cloth. ALTAR IN HONOR OF JESUS CHRIST. On the Gospel side is a [sma11 altar, the table of which] is oil-stained. In the uppermost part of the altar is a religious painting of Saint Francis of two varas in length. In the center of the altar is a crucifixion in sculpture... . and satin curtains. To the right is a statue of Our Lady of Sorrows, of one and one-third varas in height, dressed in a taffeta tunic, girdle-belt of sheer cloth, depicting the heart pierced by a dagger, a silver laurel wreath, silken veil of [exquisite] material, upon a painted mantlepiece. On the left-hand side, by itself upon another mantlepiece, is a statue of the same size of St. John the Evangelist, with a satin tunic and a cloak of coarse sackcloth. At the base of the cross is a statue of Jesus the Nazarene of a fourth of a vara in height, enclosed in a glass case. On the altar table there are altar stones, altar linen, candlesticks, dust cover, paryer cards, and a satin frontal. There is also a religious painting in a semi-gilded oval frame of Saint Catherine.

The church has two confessionals, a pulpit and a voice-reflector, all oilstained; 72 benches with backrests, a stone font for holy water, and a full-length lectern. 88

At the conclusion of the inventory of San Juan Bautista, Captain Rodriguez declared: "Aware of the care, vigilance, and constancy with which the... Reverend Father President [Diego Jiménez] and his missionaries have labored in the fulfillment of their duty, the education of the natives, and the teaching of the catechism, as well as in the efficient administration of the temporal interests of the missions, I hereby declare the College of Queretaro exonerated from all further responsibility and thank its missionaries for their faithful services."89 
Following the official transfer of San Juan Bautista, on December 15, 1772, Captain Rodriguez and Friars Jimênez and Lizarrana repeated the process at San Bernardo. The scribe carefully listed every extant item, regardless of size or condition, in the inventory. The church of San Bernardo, being of more recent construction, reflected the benefits accrued to it as the headquarters of the Rio Grande missions, "with its good doors and the entire [structure] plastered." The description of the main altar revealed glimpses of the father-president's influence in its arrangement.

MAIN ALTAR. The main altar is made up of three canopies of pretty satin with their curtains. In the principal [canopy] which is in the middle there is a statue of San Bernardo, well carved, of one and onehalf varas in height with its gold-painted pedestal and green woolen curtain adorned of fine silver needlepoint. The statue rests over a large mantlepiece of wood, covered in satin and painted. Under the principal canopy is a statue of the Child Jesus of Naples, three fourths of [a vara] which is dressed in a damask tunic, with a Brittany shirt, sandals of ribbed silk, a crown of silk flowers, and in one hand a. crystal cross and in the other a basket of ribbed silk, stuff-worked, and full of satin fruit; it has a belt of various precious stones. On a lower stand to the right is a carved statue of Our Lady of Sorrows about three-fourths of a vara with a gold-painted background. It has a crown with rays and a silver sword [piercing the heart]. On the other side there is a statue of St. Joseph with the Christ Child, of gold-painted carving of the same size over a gold-painted pedestal . . . On the last level over the altar there is an inlaid tabernacle, newly gold-plated, with its door and nave [and hanging] pendent of sheer clothribbon. The altar is of wooden boards, with its dais and table surface on one side and a bell for the Sanctus [used during the celebration of the Mass to call attention to the more solemn parts]. In one corner of the altar is a small stone fountain with a cover for preserving holy water.

In the second canopy, on the Gospel side is a crucifix about one vara in height on a wooden pedestal well constructed and painted . . . and on the side [is] the statue of Our Lady of Sorrows with a multi-Tayered dress adorned with designs of fine gold [thread] and her crown of goldplated tin and the halo of gold plate, and the statue of St. John with a flannel tunic and a purple taffeta cape, also with a gold-plated tin crown. Hanging from the canopy are purple taffeta curtains.

On the other side under the third canopy is a canvas [painting] of Our Lady of Refuge about one and one-fourth varas in height, enclosed in a gilded frame, and to its sides are the carved statue of St. Robert, about one and one-fourth varas, on a gold-painted base, with the Christ Child; and a carved statue of St. Lawrence, about three-fourths of a vara on a semi-gold painted pedestal. The curtains hanging from this canopy are yellow satin. ${ }^{90}$

When the inventory sheets had been duly signed, Fray Luis de Lizarrana officially accepted San Bernardo and San Juan Bautista in behalf of the Franciscan Province of Jalisco. The Queretarans, taking formal leave, then departed for new challenges in Sonora and Arizona. 


\section{THE VISIT OF FRIAR MORFI}

The Queretaran friars' voluntary release in 1772 of the Rio Grande missions to the Jaliscans signified a pivotal milestone in the church-state relations in the river-front community. From one vantage point it meant the passing of an epoch of active evangelization characterized by sizeable congregations, confident optimism, notable construction, disappointing setbacks and determined renewals. From another perspective it denoted the advent of a period of passive survival and transition. Unquestionably the major highlight during the Jaliscan administration of the Rio Grande missions was the visit in 1778 of Fray Juan Agustín Morfi, historian, chronicler and chaplain assigned to the staff of Commandant General Teodoro de Croix. Friar Morfi, critical yet truthful, elected to comment on the broad spectrum of society at the Rio Grande. Of the presidial settlers he wrote:

According to last year's census of [17]77, ordered by the Commandant General the Caballero de Croix, we know that without counting the families, properties, and houses of the [fifty-seven] soldiers assigned to this garrison, there are within this jurisdiction 420 men, 344 women, 242 young boys, 203 young girls, 5 male slaves, 6 churches, 4 convents, 86 stone houses, 60 adobe houses, 55 fields of 7 and under cultivation, 40 and one-half cavallerias [approximately 4,275 acres] of ranchland [distributed to soldiers for services rendered], 349 sitios for goat and sheep herding and cattle raising, 76 herds of mares, 24 herds of donkeys, 192 yokes of oxen, 2,030 head of cattle, 12,275 [head] of sheep, 2,945 goats, 561 tame horses, 124 tame mules, 55 donkeys, and 35 hogs. 91

Undaunted by climatic variations, Morfi declared: "It is extremely cold in the winter and excessively hot in the summer; but even so the climate is very salubrious and regularly comfortable for the permanent residents who were born here and for those persons from other countries who live here and have become acclimatized." 92 The friar's commentary on the Rio Grande was especially perceptive.

Another river cannot be found in all the territory than that of the Rio Grande del Norte, which is located a distance of one and one-half leagues [approximately four miles east] from the Presidio. There are no woodlands along the riverbanks, and a method has not been devised for siphoning the river water for irrigating the back lands. Unquestionably, the river is very useful and valuable as a watering place for cattle and horses, and as a source of edible fish that are abundant, such as catfish, pike, eel, flathead catfish, yellow catfish, and others. The waters of confluent rivers known in this area such as the San Pedro, Rio Puerco, San Diego, San Rodrigo, San Antonio, Nadadores, and Savina, flow into the Rio Grande on its southerly course to the Gulf of Mexico.93

With relevance to construction materials used at the missions in earlier years, Morfi's criticism of the settlers' lack of initiative in arboriculture was noteworthy. 
Everyone in this territory complains of the lack of timber for use as building materials in the construction of their homes, and for other more definite uses, but if in their condition all they do is complain, then they must want to stay. Not taking into consideration the numerous evergreen oaks, mesquite, huisache, some poplar, white willow, and cactus that can be found in many parts they (the settlers) could have at hand numerous groves of cypress, walnut, poplar, white willow, ash--all very vital--simply by applying themselves diligently to planting and irrigating them in the many marshes, large irrigation ditches, and humid places where land is abundant. No one is ignorant of the fact that these trees have done wel1, and usually when they are transplanted in town, but they still expect everything to be produced by nature alone. 94

Seemingly, nothing escaped the critical eye of Friar Morfi. The presidio came under severe review, especially the townspeople for failing to support the local church.

Finding the Presidio... surrounded by the two missions and their lands, the lands belonging to the vecinos (of the garrison), and the ranchlands . . . suffice it to say it is a regular town that could have (a population of) 800 souls including the soldiers and their families. The (military) plaza is large, well built, and nearly enclosed on all four sides. On the west side is the old and badly constructed guardhouse next to the captain's house. In front of the captain's house on the east side (of the plaza) is the space of land reserved for the church. It is important to note in this discussion that in the 78 years since this presidio was founded very little attention has been given to the actual construction and decoration of the House of God.

Hardly any progress has been made on the church that was started a few years ago. The building, which is inadequate for the number of townspeople, is still in the same condition as when it was started. The presidial chaplain has been compelled to celebrate Mass in the small room designed as the Sacristy, which is unpainted and without doors and other decorations except for the altar and a wooden cross next to the wa11. A very indecent situation! But true. Moreover, the ornaments, holy vessels, necessary books, bell, azetre (holy water basin), and everything else which is indispensable in a church (are barely avajlable); the rest belongs to the presidio. The soldiers depend upon the civilians (for church support); the civilians depend on the soldiers; and in the meantime while this doubt is resolved Domus Dei de Serta est (the House of God is to be served).95 
In his detailed commentary, Morfi touched upon a sensitive issue, land distribution, that affected church and state relations in the community for the remainder of the Spanish colonial period and extended into the formative years of Mexico's national experience.

It cannot be denied (he wrote) that the settlers within the Presidio barely possess the basic amount of land for the construction of their houses in the town 1ots. From this place repeated complaints and well-written petitions have originated frequently against the two adjacent Missions of San Juan Bautista and San Bernardo. The Tands given to the Indians have always been viewed as land

grants... (but the settlers) have not stopped clamoring for an adjudication which will be beneficial to them. But in reality, if I am not mistaken, it (an adjudication) would be contrary to all reason and without foundation.

The settlers of Rio Grande (the presidio) in their ranches and in their immediate areas possess much more land, and sometimes better advantages, than the land grants of these two communities of recent converts (Indians). Those others (the civilian settlers) are owners of two natural springs of frest and plentiful water which from their sources begin to irrigate their lands, fertilizing their fields, and enriching the owners. The mission Indians, quite to the contrary, have not asked for this water, (especially) after one considers the imponderable costs, much work, and incredible fatigue (expended to obtain water via) two large and expensive irrigation ditches which they excavated, a distance of 18 Teagues ( 46.8 miles) to San Juan and at least 20 leagues (52 miles) to San Bernardo, without taking into account the requisite annual expenditure of 300 to 400 pesos to clean out the canals. 96

Regarding an apparent disproportional distribution of non-mission land, Father Morfi criticized the control of pioneer families related to the presidial command, specifically Ramön, Hernández, Rodriguez and Eça y Müsquiz. .

The point which is worthy of special reflection (declared Morfi) is the great confusion which exists among those owners in order to know and recognize their lands and boundaries. Their own titles (documents) confuse them. Some land grants overlap others. Only a new distribution would prevent the disputes that have started to occur. I have witnessed litigation in which even with the titles and documents in hand, one could not locate any of the boundaries needed to conduct the surveys of the lands, the confirmation of which has to be obtained from the special magistrate, Don Xavier de la Garza, a settler of the Presidio. 97

The aspect of Rio Grande society that generated the least criticism, albeit pithy, was the missions. Describing the location of San Juan Bautista as a 
hi11top less than a quarter-league west of the presidio, Father Morfi commented on the architecture and the irrigated farm lands.

It has a very spacious church (he wrote) of good architecture, even if its facade, the tower, and one of the side chapels are on the brink of ruin. The gaudy furniture and decorations of the church, like the property of the convent and the mission, are listed individually in the inventory prepared for the formal transfer (of 1772) . . . The convent is very spacious, the granary and the workshop are amply extended; everything is constructed of stone, as are the houses of the Indians.

The source of the spring waters that serve this mission in irrigating its lands is about 15 to 20 leagues away. This water is conveyed via a large and expensive irrigation ditch to the area surrounding the mission. It (the mission) has the right to obtain water requisite to its needs from the spring granted to the Presidio. From the headwaters of the first spring (the mission's source of water) many good lands could be irrigated, such as those fields which cannot be cultivated because of the long distance from the mission. These waters and those of San Bernardo could be united in one single irrigation ditch to irrigate fields which al though fertile are too far from the settlements here. 98

Morfi's description of San Bernardo was quite brief.

What we have just said about the antecedent Mission (of San Juan Bautista) we can also affirm about San Bernardo. It is situated to the east of the Presidio, divided only by a marsh the waters of which belong to this Mission. Its construction materials, its gaudy furniture, its properties, and its (Indian) families are clearly described in the inventory . . . The Indians of one or the other (mission) find themselves with little instruction in trading and in social graces that today it will be very difficult, if not impossible, to educate them to estimate, to trade, and to manage their properties by themselves. ${ }^{99}$

In a private diary, obviously not intended for public scrutiny, Morfi inscribed candid observations that cast a different, indeed humanistic, 7 ight upon the Jaliscan friars' administration of the missions. Following the arrival of the commandant general's official party at Presidio Rio Grande del Norte, Morfi outlined the activities that transpired on December 22, 1777, beginning with a curt comment about the weather. 
(The day is) cloudy. The three religious, Escolta (missionary of Peyotes), (Fray Manuel) Pérez, and Murto (also of Peyotes) came (to the presidio); I accompanied them to Mission San Juan, which is very beautiful, (it has a) wel 1-constructed church with its transept, one wall of which is out of plumb, (it has) a very good altar, many decorations in good condition, four chalices and a monstrance, a spacious convent that can accommodate several friars and the Indians' houses in fair arrangement. For the padre's visit the Indian women divinely sang the Alabado (hymn in honor of the Eucharist) and Gozos (poems in praise of) Our Lady of Guadalupe. I ate Tunch, and in the afternoon we went to Mission San Bernardo, which is in better condition; it has more inhabitants, the sacristy is better furnished, (although) the church is in a sad state of repair and the Indian huts are too far removed from the rest of the people. (There is) a large church with a dome, the construction of which was initiated by Father (Diego) Jiménez; a few of the church's sacred ornaments are on loan to Presidio Rio Grande and to other presidios... . The Indian women of San Bernardo admirably sang the Salve (Regina) and the Alabado. 100

\section{THE LAST MISSIONARIES: THE FRIARS OF PACHUCA}

For three years after Father Morfi's renowned visit, the Jaliscan friars retained control of the Rio Grande missions. The viceregal government, as late as the 1770 's, continued the policy of providing yearly sinodos, in the amount of 450 pesos, to the Franciscans in Coahuila. As compared to the Texas field, where the College of Zacatecas generally assigned two friars per mission, at the Rio Grande the Province of Jalisco, lacking personnel, could only maintain one missionary at each religious outpost. 101 Owing to the fact that their provincial headquarters of Guadalajara was strategically situated in the western corridor to the Sonoran frontier, Commandant General Teodoro de Croix convinced the Jaliscans to give up the Coahuila missions in order to join other religious volunteers in the desert northwest. Hence, in October 1781, in deference to Croix' request, the Jaliscans transferred their missions to the discalced friars of the new Apostolic College of San Francisco in the mining community of Real de Pachuca. 102 The formal inventories of San Juan Bautista and San Bernardo, conducted by Capitan Manuel de Crecedo y Velasco, Fray Domingo Juncosa of Jalisco and Fray José de la Concepción David Garcia of Pachuca, progressed with dispatch. As revealed in the inventory of San Juan Bautista, the Jaliscans, during their brief tenure, remodeled one of the rooms in the convent as a library, the contents of which reflected the metropolitan values of the occupants. The library included four partly covered volumes of theology, eight volumes of unbound documents, eight volumes of tautology, one volume of contracts and deeds, five record books of baptisms, marriages and burials of Spanish settlers, five record books for the Indians of the mission, two account books in box containers and a modest assortment of books on other topics. 103 
Confirming Father Morfi's candid assessment of San Bernardo, the inventory of 1781 disclosed that the Indians' pueblo consisted of:

forty houses of stone and mud, four of which lacked roofs, one was without a door, but the remaining thirty-five had windows, ordinary doors, and a few had security locks. Altogether the houses form two streets, with the plaza closed off on one side by the partly constructed Church of stone and mortar, of which the spacious sacristy with its dome and the baptistry with its dome have been completed. The main body of the Church has half of the cornices for the dome completed up to the required height; and the other half needs three varas of work in one section and four varas in another to reach the uppermost leve1. There is a lime kiln, a large corral enclosed by a stone wall on three sides and a post fence on the other, and an unfenced orchard with a few fruit trees and poplars. 104

The arrival of the Pachucan friars indicated an era of prudent renewal. Under the able leadership of Fray Josê David Garcia, the missions of the Rio Grande underwent renovation and consolidation of effort. Within five years after assuming administrative responsibility, Friar Garcia reported on the progress of San Bernardo.
At this Mission there is nothing more fundamental than the work of the Indians, which consists of a good planting of corn, beans, cotton, and chili, and in the past three years in sugar cane, the harvest of which in the last two years has produced pilancillo of excellent quality, and the basic necessities for the upkeep of the Mission which is not insignificant. . . Every Sunday, with the assistance of the missionary priest and the native alcalde (of the pueb7o), sufficient provisions, in- cluding surplus corn, are distributed to the Indians for their sustenance; and during Lent, when meat rations are prohibited for a few weeks, the Indians are given beans, as also during special work seasons such as planting the farm lands and cleaning the irrigation ditch. The resident missionary utilizes the surplus grain to exchange for cloth and other necessities (for the Indians), as he does for the distribution of seeds, salt, soap, and tobacco.105

To increase agricultural productivity, to guarantee annual harvests, and certainly to serve as work models for the natives, the Pachucans continued a practice, initiated earlier by the Jaliscans, of employing civilian laborers at both San Bernardo and San Juan Bautista. Acknowledging gains and 1osses, Friar Garcia informed the nearest episcopal office about San Juan Bautista's material advancement. 
Likewise it has at the present time four thousand two hundred head of sheep and a herd of one hundred goats, (and it has) three hundred and fifty mules and horses, including thirty tame horses. (The mission) is well equipped in all types of tools for farming and the workshop; it has the same (number of) servants as San Bernardo, paid the same salary more or less, and in the season for cleaning the irrigation canal and planting the corn fields, almost one or the other has to hire a few more (servants to do the work) because of the laziness of the Indians. These two missions have expended many pesos replacing farm and workshop tools which were missing when we accepted their transfer, likewise to augment the herds and the equipment in the Indian quarters such as pots, copper kettles, grinding stones, and griddles which they direly needed. 106

\section{THE BISHOPRIC OF NUEVO LEON AND THE PACHUCANS}

During the viceregency of Antonio Maria Bucareli, when the Bourbon Reforms reached their zenith, an ecclesiastical reorganization upon which the Pachucan friars capitalized was the creation in 1777 of the new bishopric of Nuevo Reino de León. 107

As the final decade of the 18th century unfolded, the guardian of the Apostolic college de Pachuca, in view of the government's uninterrupted assistance, apprised Viceroy Revilla Gigedo on current developments at the Rio Grande missions. He reported that San Juan Bautista, under the care of Fray Manuel Gorjōn, while congregating new groups of natives, had achieved notable progress.

The Indians of this Mission (wrote Fray Ysidoro Puertoliano) are of the Pampona, Filijaya, and Borrados de la Costa del Oriente. Its industry and program of work consists in cultivating and harvesting the fields. On a regular basis, this Mission plants 10 fanegas (approximately 88 acres) of corn, two ( 17.5 acres) of beans, and one almud ( 4.4 acres) or two of cotton; and four or five cargas ( 20 to 25 bushels) of wheat, the harvest of which is milled locally. The water of some natural springs is so abundant that as much as two buyes $(5,193$ gallons) gush forth at the source, but, owing to the distance of eleven leagues (28.6 miles) of acequia, only one half of the volume reaches the Mission. It (the mission) has a tapestry shop where the Indians weave blankets from the wool of the sheep, as well as ordinary cotton cloth, for themselves. The pastoral assets which it has at present are 520 head of cattle including oxen, 2,000 head of sheep and goats, a herd of 129 horses including tame ones, 
and 76 mules, both tamed and untamed, which constitute a suitable string. This Mission has numerous salaried servants who are not Indians, for cleaning the irrigation canal, herding the livestock, and for cultivating the fields, on account of the fact few Indians are skilled workers. The individuals (who comprise the mission's native population) are 62 within whom are 14 marriages, 9 widowers and widows, 5 bachelors and 20 boys and girls. 108

About Mission San Bernardo, administered by Fray Antonio López, the college guardian wrote:

Its Indians are Paco, Paquache, and Borrados of the same Costa Oriental. Its occupation is the same as the antecedent (mission), with the exception being that its cultivation of farmland is less, since corn production, for lack of water, does not exceed seven or eight fanegas (approximately 61 to 70 acres); one fanega ( 8.8 acres) of beans, and one almud (4.4 acres) of cotton. The natural springs which benefit the Mission are very abundant, perhaps more so than those of the former (Mission San Juan Bautista), but their source is located 25 leagues (65 miles) away. On account of the extensiveness of the irrigation canal much water is wasted, and (the residue) barely reaches the Mission's farmland (which for the very reason is about one-eighth, and in some years none whatsoever). Therefore, it has become necessary to cultivate fields as much as 18 Teagues ( 46 miles) away from the Mission. To dredge this irrigation canal, which is conducted every year, 1aborers from the presidios are hired, which results in considerable expenditures. In addition (to these expenses) there are the various servants in charge of herding the livestock. Among the livestock the Mission has 330 head of cattle including the oxen; 6,000 head of sheep; and 140 tame horses, mares, and colts. It has a tapestry shop as in the antecedent (San Juan Bautista) and a mill for grinding wheat, of which from three to four cargas (15 to 20 bushels) are planted annually. The individuals who inhabit the Mission during the daytime number 80 , in the following categories: 15 marriages, 26 widowers and widows, 12 unmarried men and women, and 12 boys and girls. It should be noted that at this Mission, as in the other, the numbers in the categories refer to Indians, because the servants do not live at the missions. 109 
Allowing for probable inflation in statistical data, the contents of the report provided insight into other aspects of the human experience in the 1790s. On the one hand, the principal economic activities, farming and livestock raising, despite environmental handicaps, continued to support the missionary enterprise at adequate levels. On the other hand, the friars, due to the spirited competition of other missionaries in the Lower Rio Grande Valley settlements, encountered serious difficulty increasing the size of mission congregations, as noted in the presence of new groups of natives identified as Borrados de 1 a Costa. In turn, the reduction in the size of the congregations affected the available pool of skilled workers at the missions which, of necessity, compelled the friars to hire civilian laborers. Cognizant of frontier realities which required the transfer of secular responsibility of missions to the Commandancy General of the Interior Provinces, Viceroy Revilla Gigedo prepared a detailed commentary on the subject for the royal court in Spain. Regarding the frontier of Coahuila, the viceroy praised the efforts of the Franciscans at the Rio Grande.

The churches are adequately maintained, generally constructed of adobe, with the exception of San Juan Bautista which is of rock construction, as is likewise of similar stability San Bernardo, begun by the religious of the College of Querêtaro, which when completed could become the best constructed mission in the entire province (of Coahuila) . . .110

\section{SECULARIZATION: EXEMPTION FOR THE RIO GRANDE MISSIONS}

Material and human shortcomings to the contrary, the two missions of San Juan Bautista and San Bernardo, in the opinion of the guardian of San Francisco de Pachuca, qualified for secularization and transfer to the diocesan clergy. 111 In April 1794, Commandant General Pedro de Nava issued a decree mandating the secularization of all missions in the Interior Provinces which had been in existence more than 10 years and also the distribution of the temporal property to the neophytes. 112 Even before Nava's decree became public, the governor of Coahuila, Miguel José de Emparân, intervened with the fiscal office of the Commandancy General to exempt the Rio Grande missions from secularization. 113 Clearly the interests of the state, in granting the exemption, out-weighed the considerations of the apostolic college, which, in view of earlier episcopal connections in Nuevo Leön, tacitly respected the decision. For the remainder of the colonial period, regardless of local agitation for secularization, the Pachucan friars persevered in their commitment to the Rio Grande missions.

\section{THE PRESIDIO: BASTION OF THE CROSSROAD}

In the 1790s, Presidio Rio Grande del Norte, reinforced earlier by an increase in personnel to 96 men, did not have sufficient strength to deter Indian aggression completely but was able at least to slow down the momentum. Much to the chargin of the commandant general, the outpost still lacked a perimeter wa11, parapets, trenches and palisades, 114 deficiencies which the presence of numerous settlers helped to offset. Occasionally Lipan Apache marauders slipped through the line of defense and attacked exposed positions, the most vulnerable 


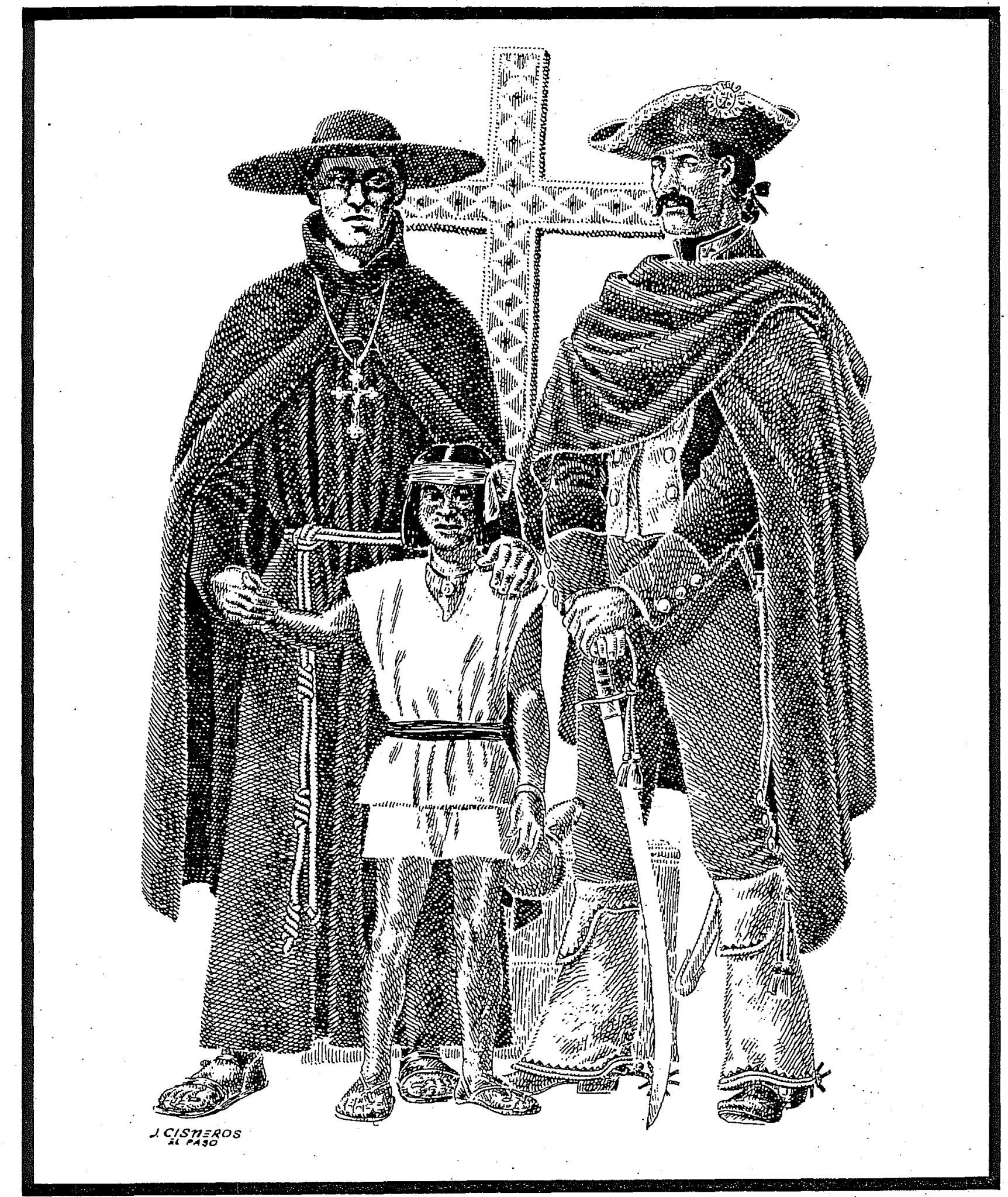

Figure 3. A Franciscan Missionary and a Presidial Captain, with a Native Boy. The illustration depicts the union of Church and State in the Borderlands, with the native boy representing the object of conversion to Christianity. Courtesy of the Bexar County Historical Commission. 
being the adjacent missions. Since the losses usually involved livestock, conceivably the object of Apache incursions was finding substitute sources of fresh meat to compensate for territorial dislocations created elsewhere by Comanche hostility. Indicative of shifting migratory patterns, the appearance of Comanche warriors at the Rio Grande in the early part of the decade, substantiating the inter-tribal confrontation theory, compounded the defense burden of the presidio.lis As a reflection of these developments, the military reports of the decade contained frequent complaints about Lipan aggression. In the summer of 1790, for example, Apaches raided the two missions various times, stealing livestock and killing several herdsmen. ${ }^{116}$

\section{SECULARIZATION: A PERENNIAL COMPLAINT}

The recurring attacks of Lipan Apaches and their enemies undoubtedly motivated the inhabitants of the presidio to petition the government for secularization of mission lands, based on the plausible assumption that a buffer zone of ranches and farms managed by civilian owners would reduce Indian hostility at the river crossing. A factor which assurediy influenced the settlers' demands for secularization was a census, compiled in 1797-1798, which disclosed that the population statistics of San Juan Bautista listed only 10 families (for an aggregate congregation of 52 persons, including eight squatters) in comparison to 12 families for San: Bernardo, not counting the categories of widows, widowers and unmarried (for a total of 73 persons). In contrast to the foregoing data for the missions, the census registered as active farm laborers 27 settlers at the presidio, not taking into account other individuals who, although identifying themselves as agricultural workers, were either inactive, poverty-stricken or physically incapable of performing manual labor.117 In any case, by the end of the decade, convinced of the legitimacy of their cause, the presidial settlers reminded the provincial governor, Antonio Cordero, about their contributions to frontier defense. Typical of the petitioners was an attorney, José plácido de Morźon, who represented the settlers in filing a claim to the riparian rights and arable lands belonging to Mission San Juan Bautista. 118

The commandant general, perhaps as a routine gesture to placate the settlers' complaints, directed the presidial captain of Rio Grande to submit a preliminary assessment of the missions, farmlands and irrigation canals to the governor of Coahuila. In compliance with the directive, Antonio Toledo y Oquillas informed Governor Cordero about the arable lands and sources of irrigation water, reserving the final section of the report for a commentary on the Indians' apparent lack of initiative as agricultural workers. Accordingly, in the event of secularization, Captian Toledo recommended a local settler, José de Leốn Curiel, for the position of public trustee of the two missions of San Juan Bautista and San Bernardo.119 To support the petition for land distribution, Morzon, the presidial settlers' representative, prepared a review of the missions" history, emphasizing hallmarks of a century of operation. Acknowledging the protection extended to mission Indians by crown law, Morzon confined his petition to the extensive agricultural fields in the upland country near the natural springs, underscoring his point with the observation, obviously a hint on the virtues of private initiative, that presidial settlers had justifiable rights to their claims. 120 


\section{THE RIO GRANDE MISSIONS AT THE TURN OF THE CENTURY}

As the 18th century ended and the initial decade of the succeeding 19th century commenced, the Pachucan friars continued their apostolic work at the Rio Grande. The theme which dominated the final phase of the colonial period at the crossroad was secularization and distribution of mission lands. Seemingly unconcerned about this constant irritant, the guardian of Pachuca, Friar Ysidoro Puertollano, requested permission of the viceregal office to recruit new missionaries in Spain for frontier service in North America. ${ }^{121}$ In the meantime at the Rio Grande community, the settlers accelerated their efforts to obtain land at the expense of the mission grants. Luis de la Garza, the justicia of Rio Grande, in 1807 drafted another proposal in behalf of the settlers. He readily admitted there was no individual who was knowledgeable of the exact boundaries of the extensive mission lands. When the Queretaran missionaries accepted the lands for the Indians a century earlier, there were relatively few civilian settlers at the presidio, and circumstances did not dictate a need for precise demarcation. Therefore, the solution which De la Garza advocated was hiring a trained engineer to survey the area and prepare a topographical map denoting longitudes and latitudes. Only through this type of document, he counseled, would it be possible to determine the magnitude of the land grants and to identify the location of natural springs, the directional course of irrigation canals, and the delimitations of such wel1-known places as Hacienda de San Blas, Ranchos del Salitrillo and San Lucas, Villa de Laredo, Hacienda del Carizal, Rancho de Santa Ana and other southern establishments. De la Garza proposed a fair distribution of land and water rights to the mission Indians, after which eligible presidial settlers would receive title to the surplus outlying terrain. As a form of reciprocity, showing the continuing interdependence of church and state, he recommended the designation of San Juan Bautista as a parish to serve both settlers and former mission Indians. ${ }^{122}$

Progressive and equitable as De la Garza's plan appeared on paper, secular authorities failed to implement the suggested changes, probably due to subtle resistance from the ecclesiastical hierarchy. The fourth Bishop of Nuevo León, Primo Feliciano Marin de Porras, expressed his opinion on the subject of secularization of the Rio Grande missions to Commandant General Nemesio Salcedo.

I wish to inform Your Lordship (wrote the bishop) that I have the greatest determination that some day those poor Indians will enjoy political and honorable freedom which will be granted to them by our laws, and that they will escape the bondage which has degraded them . . .123

Although not opposed to the ultimate goal of secularization, the bishop deflected the thrust of the issue toward the covetousness of the presidial settlers.

For that reason (the bishop continued), I find it proper to advise Your Lordship . . . that it is necessary to chastise the we11-known greed the presidial settlers have manifested toward the extensive land and (water) of these poor (Indians) for the different fields of agriculture. It is common knowledge that the Spaniards (the settlers) will receive the extensive surplus land upon which to assert their industry. ${ }^{124}$ 


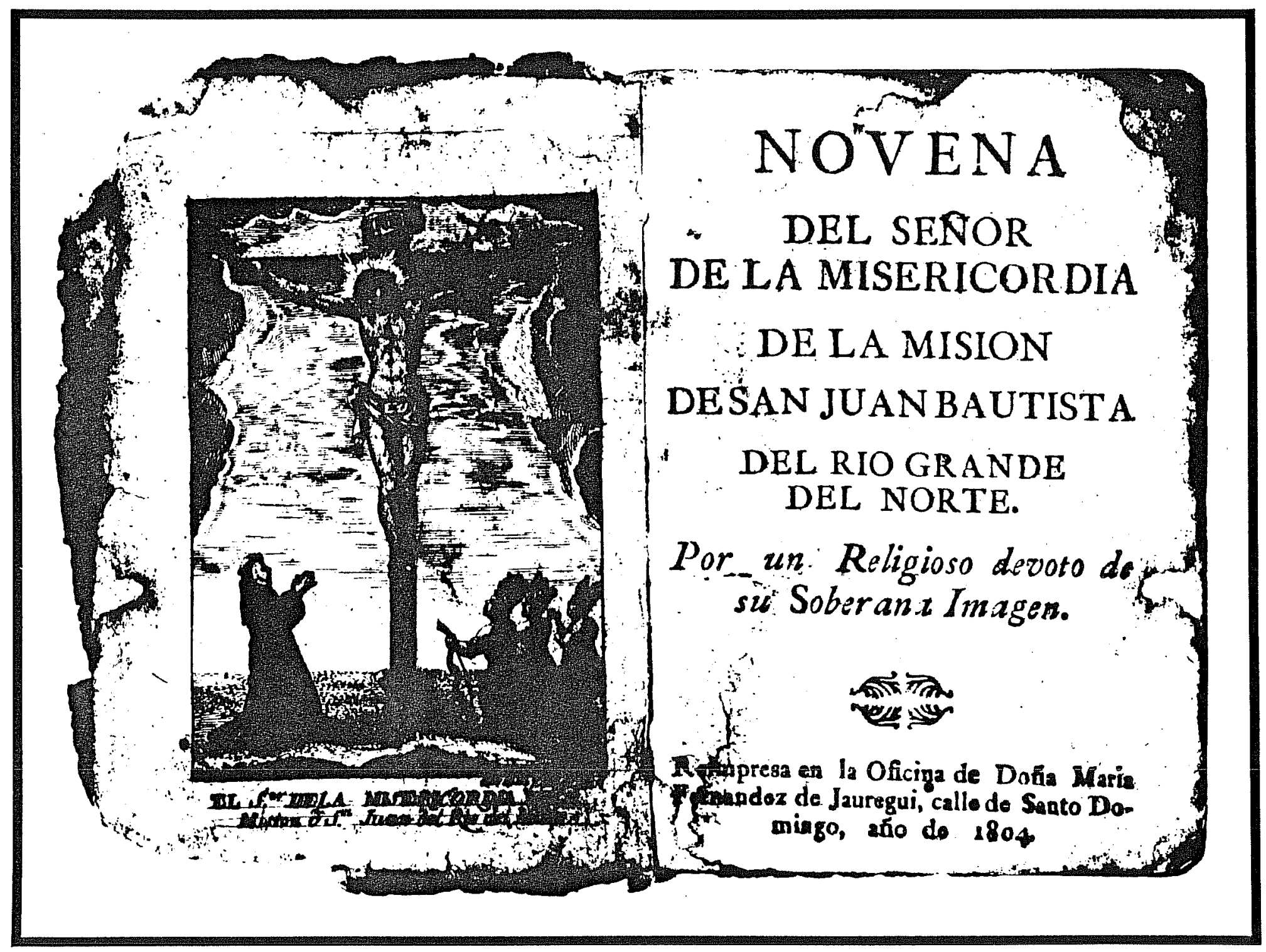

Figure 4. Frontispiece and Title Page of Novena Booklet Used at Mission San Iuan Bautista. Courtesy of Israe1 Cavazos Garza, Monterrey, Nuevo León, México. 
However, so as not to give an impression of obstinancy, Bishop Marin de Porras pledged cooperation in the secularization process as soon as diocesan clergy could be found to assume responsibility for the future parishes. ${ }^{125}$

The successor guardian of Pachuca, Friar Francisco Gutiêrrez, in the spring of 1809, informed Commandant General Salcedo that the college had no interest in the maintenance and preservation of the Rio Grande missions other than the apostolic ministry. Therefore, with respect to the matter of secularization, he acknowledged receipt of a royal decree, dated January 22, 1809, which subordinated the Franciscans' control of frontier missions to the priorities of the state. Accordingly, the father guardian referred the problem to the commissary prefect in charge of missions in Coahuila, Friar Manuel Gorjôn, who presided over the Franciscan estab7ishments at the Rio Grande. 126 By early summer, in view of the declining number of resident Indian families, Friar Gorjón suggested a compromise of waiting unti] the autumn harvest and roundup, after which the lands and properties of San Bernardo could be partially secularized, allowing the native families who desired to continue in the mission system to be integrated with the population of San Juan Bautista. The natives . who elected to become property owners would receive land, water rights and five head of cattle to begin their herds. The church of San Bernardo, with its religious ornaments and sacred vessels, would become the center of a new parish!27 Anticipating prompt approval of the compromise for partial secularization, the college administration early in 1810 reduced the assignment of religious personnel at the river crossroad to one person, leaving Friar Gorjön, age 54, as the resident missionary at San Juan Bautista with itinerant duty at San Bernardo. 128 Actual secularization, almost on the threshold of realization, eluded the proponents for several years while the viceregal government faced the most serious challenge to its existence.

\section{THE REVOLT OF MIGUEL HIDALGO}

The sudden outbreak of Father Miguel Hidalgo's insurrection in September 1810, compounded by Napoleon's military aggression in the Iberian peninsula which stymied effective government, disrupted the tranquility of the vice-royalty of New Spain. With turbulent fire and sword, yet devoid of specific declarations, Hidalgo's insurgency spread north into the borderlands, turning eastward into Coahuila and Texas in search of sympathizers. The rapidity with which the movement engulfed the Texas provincial capital of San Antonio de Béxar inspired rebels on both sides of the Rio Grande to seize important centers of royalist authority. In the confrontations that developed, the ebb and flow of political unrest in Texas significantly influenced conditions in the provinces to the west, particularly in adjacent Coahuila with its river crossroad as a conspicuous, albeit isolated, landmark. In the spring of 1811, a counter-revolutionary movement restored royalist control in Texas and penetrated Coahuila, the result of which was the capture and execution of Father Hidalgo and his chief lieutenants. Early in 1813, the violence of insurgent warfare returned to Texas, culminating in the rebels' assassination of Governor Manuel Salcedo, nephew of the commandant general, and the royalists' subsequent victory at the Medina River. Throughout these swift encounters, the presidio at the Rio Grande, in spite of its limited resources, provided back-up support to royalist forces in Coahuila, Texas and Nuevo Santander. ${ }^{129}$ In a 17 probability, the fact that the 
Rio Grande crossroad was not a full-fledged Spanish municipality spared its inhabitants the somber consequences of overtly endorsing the undefined goals of the insurrection. Like the down-river Villa de Laredo, the presidio and the mission pueblos remained steadfastly loyal to the political system that had responded, however sluggishly, to the problem of land distribution.

Although royalist defenders suppressed Hidalgo's rebellion, a few embers remained smoldering in the central and eastern corridors of New Spain. Now and then latent firebrands flared again, creating uncertainty and unrest, only to be deterred by vigilant sympathizers of the crown. The fluctuating fortunes of the insurrection completely halted the course of secularization of the mission properties at the Rio Grande crossroad of empire. In the spring of 1815, most likely in response to the settlers' perennial complaints, the Royal Tribunal of the Audiencia of Mexico City reopened the issue by reviewing all practical decisions made at the local and provincial levels in 1808 and 1809 to initiate the process. Owing to the disorder Hidalgo's revolt precipitated in Coahuila, and plausibly to attract loyal support for the government in the crisis, Commandant General Salcedo petitioned the Royal Tribunal for an expeditious judgment on the matter of changing the legal status of the Rio Grande missions into civil pueblos. After examining the documentation and favoring the objective, the court advised government officials in the Interior Provinces to proceed with secularization plans whenever peaceful conditions allowed. Aware that secularization might require expenditures, the court informed the Real Hacienda (treasury) of its decision. 130 In turn, the fiscal officer of the treasury promptly notified the commandant general that, having secured the concurrence of the Bishop of Nuevo León, the process of distributing lands and water rights to mission applicants and presidial settlers should proceed without delay at the earliest convenience.131

During the turmoil fomented by Hidalgo's revolt, when an incipient uprising transformed itself into an independence movement, the Presidio Rio Grande del Norte fulfilled its purpose as sentinel of the crossroad of empire. At higher levels of military responsibility, the constant threat of insurgency motivated royalist administrators to divide the Commandancy General of the Interior Provinces into western and eastern divisions, with Joaquin de Arredondo assuming the leadership in 1817 for the latter unit, with headquarters in Monterrey, which included Coahuila, Texas, Nuevo Leôn and Nuevo Santander. 132 Likewise, at Presidio Rio Grande del Norte, old-line leaders of the transitional period from one century to the next retired from the scene, allowing successors to take their place. An example of rapid turnover in command occurred in the case of Captain Ramón Perea, who succeeded Mariano Varela in October 1815. Approximately a year later, Captain Perea's service record indicated that at age 62 he was in "robust hea1th." Born in Villa de Altamira in 1755, Ramón Perea enlisted in the army as a common soldier when he was 30 years old. Achieving quick promotions through the lower ranks, by 1788 he earned the chevrons of sergeant, remaining in that distinguished grade for 13 years. Just prior to the outbreak of the Hidalgo revolt, Perea advanced to the officer corps as alférez. Faithful to the royalist cause, he served with the Third Compania Volante of Nuevo Santander combating insurgents from 1811 to 1814, during which period he received promotion to captain. Dedicated as Perea was to the crown, by 1817 he admitted the rigors of a military career of 32 years had taken their to11. Accordingly, he asked Commandant General Arredondo for permission to 
retire from active duty. Given the garrison's geographic position, exposed to potential danger by hostile natives and belligerent rebels, Arredondo wasted little time in appointing Captain Rafael González as acting commander. By the end of spring 1817, Ramón Perea retired with an annual pension equal to onethird of his basic salary. On June 16, Captain Juan José Llano assumed charge of Presidio Rio Grande del Norte. 133

\section{THE RIVER CROSSROAD ON THE EVE OF MEXICAN INDEPENDENCE}

The relative frequency of leadership changes at the presidio, in all probability, was symptomatic of the tensions created by the insurgents' interminable struggle to achieve complete independence from the mother country. For more than a decade the strains and stresses of the rebellion forestalled the state's honourable intentions to secularize the Rio Grande missions into civil communities and to distribute the surplus land among the numerous settlers at the presidio. Toward this end church officials, both regular and diocesan, pledged their full support and cooperation. In mid-June 1819, almost on the eve of Mexican independence, the guardian of Pachuca reminded the Real Hacienda of the college's resolution, in conformity with the wishes of the Bishop of Nuevo Leon, to relinquish the missions to secular authorities. 134

In the meantime, the state representatives at the local and upper echelons, concerned more with personal survival, disassociated themselves from the question of secularization. Militia Captian Joaquín Muñoz de Terna of Presidio Rio Grande lamented to Commandant General Arredondo that he had not received just compensation, including salary in arrears, for privations he and his family had suffered in loyal service to the crown.135 Arredondo, with bureaucratic finesse, assured the viceroy that militiamen were not deprived, since they resided in the comforts of their own homes. More important to the commandant general in 1820, however, was interpreting correctly the significance of the "Sovereign Revolution" that had occurred in Spain. 136

The "Sovereign Revolution," an external event that jolted the royalist structure in New Spain, was the reintroduction of the liberal Spanish Constitution. Drafted in 1812 but not formally implemented until the end of the Napoleonic Wars in 1814 when Ferdinand VII returned to the Spanish throne, the constitution altered the traditional center of power from absolute monarchy to that of shared responsibility between crown and parliament (cortes). Other important changes in the liberal document were its anti-clericalism and the theoretical equality of the American colonies and the Spanish peninsular dominions. Between 1815 and 1820 the monarch's reclamation of royal power nullified the constitution at home and in the colonial empire. In the spring of 1820, the peninsular army, concerned about its corporate prerogatives, forced the king to reinstate the liberal document, thus setting in motion the "Sovereign Revolution" to which Arredondo alluded. In New Spain, royalist officials, precarjously holding their positions of authority, tacitly accepted the constitutional changes without resistance. In October 1820, Commandant General Arredondo reconciled himself to the assistance of an advisory council, the Provincial Deputation, composed of delegates from the Eastern Interior Provinces. As 1820 gave way to the hallmark year of Mexican independence, royalists defenders in the borderlands faced the future with uncertainty. On February 21, 1821, Colonel Agustin Iturbide, royalists-in-rebellion, proclaimed his famous Plan of Iguala with its captivating three guarantees of independence, religion and union. With this document, coupled 
with the inherent anti-clericalism of the Spanish constitution, Iturbide assembled a viable combination of conservative elements to conclude the prolonged struggle for Mexican independence by persuading leaders in the provincial capitals and strategic towns to join his movement. In mid-summer the Coahuila town of Salti110 fell to Iturbide's followers, leaving Monterrey, headquarters of the Commandancy General of the Eastern Interior Provinces, as the next prime objective. On Tuesday, July 3, unable to resist the pressures for independence any longer, Commandant General Arredondo surrendered in Monterrey and reluctantly endorsed the Plan of Iguala. Subsequent7y, the orderly transition that prevailed in the neighboring province of Texas signaled the end of the colonial period in the borderlands. 137

\section{THE CROSSROAD IN RETROSPECT}

The news of Arredondo's capitulation ended forever the possibility of resolving amicably the presidial settlers' demands for land distribution near the crossroad of empire. When it appeared evident that Iturbide's popular insurrection would triumph, the Pachucan Friars abandoned the Rio Grande missions to the ravages of vandalism. In all likelihood, they did so sorrowfully, given their proclivity toward the royalist system. The problems of secularization and land distribution, caught up in the fast-moving events of post-independence, receded into the background as more important considerations of statecraft dominated the center stage. The decline of San Juan Bautista and San Bernardo, a Tready noticeable since the closing decade of the 18th century, ironically forecasted the end of an era. The Pachucans' willingness to relinquish the mission properties while the ecclesiastical centers were still active and productive was an indication that the political purpose of the enterprise had been achieved. A11 the same, the tendency of state officials to delay secularization at the Rio Grande, when the process had commenced in Texas, merely compounded the problem until the Hidalgo revolt made it impossible to solve it methodically.

The Rio Grande missions and presidio, symbols of church and state, served the imperial designs of the Spanish crown for a century and a quarter. In the formative years of the 18th century, the missions and presidio, frequently on the brink of collapse, survived the rigors of the borderlands because of the determination and tenacity of able frontier leaders. Close cooperation between the Queretaran missionaries and presidial soldiers characterized the history of the first 50 years. In the second half of the 18th century, the introduction of the Bourbon Reforms upset the delicate balance of church and state. Hereinafter the interests of the state prevailed, as in 1772 when the Queretaran friars voluntarily relinquished their administration of the Rio Grande missions to Jaliscan Franciscans, who, in turn in 1781, transferred the responsibility to the Pachucans. The achievements of the Queretarans in establishing firm foundations in the temporal and spiritual realms facilitated the transition to the Jaliscans and then the continuation by the Pachucans.

In the development of the Rio Grande missions, the presidio played a significant role, for without its proximity it is unlikely the ecclesiastical enterprises could have survived the aggression of hostile natives. Admittedly, what the presidio lacked in military formalism it compensated in providing sufficient protection to attract numerous settlers who clustered around it, thus reinforcing the security of the crossroad. Over the years, the presence of an increasing 
civilian population contributed to the problem of land distribution and water rights. On the local level, al though at times the needs of the state clashed with the interests of the church, in reality the two institutions needed each other for survival and companionship in a remote frontier area. From the beginning until the end of the colonial period, the missions and presidio at the Rio Grande crossroad remained loyal to the government that founded them, visible reminders of the union of church and state. The secularization of the once productive mission lands became part of the unfinished agenda for the successor government of independent Mexico when the surviving vestiges of the colonial past, both human and physical, merged into the Villa de Vicente Guerrero. 
TABLE 1. SAN JUAN BAUTISTA, 1706

Native Population

Christian Indian families married according to the rites of the Catholic Church 26

Christian Indian bachelors 16

Unmarried Christian Indian women 6

Christian Indian boys 30

Christian Indian girls 23

Christian Indian boys (grouped separately) 5

Indian men receiving instruction in

Christian doctrine

Indian women receiving instruction in

Christian doctrine

Indian gentiles (men)

Indian boys receiving instruction in

Christian doctrine

Indian girls receiving instruction in

Christian doctrine

Total Native Population

Agricultural Production

Crop Acreage in Cultivation

Corn $\quad 10$ fanegas (16 acres)

Beans 1 fanega and four almudes (3.6 acres)

Cotton

62 almudes ( 31 acres)

Livestock Production

Cattle: $\quad 48$ head

Sheep: 135 head

Goats: $\quad 320$ head

Equipment and Tools
14 yoke of oxen
1 iron bar (broken)
2 muskets
6 axes
2 sma11 saws
8 ploughshares, with necessary accessories
1 adze
7 hoes
2 carpenter's planes 
TABLE 1. (continued)

Buildings and Grounds

Weavers' looms for cotton and wool (operated by Indian women) Missionaries' living quarters (with accommodations for five friars)

Indian quarters (temporary shacks)

Granary for grain storage (corn)

Garden grove with adobe wall

Indian granary (for goods obtained outside of mission compound)

Flat-roofed adobe kitchen (separate from convent)

Stable for horses

Chicken yard

Source: Fray Isidro de Espinosa, Report of Mission San Juan Bautista, October 23, 1706, AGN, P.I., 28: 339-340. 
TABLE 2. SAN BERNARDO, 1706

Native Population

Christian Indian families married according

to the rites of the Catholic Church

Christian Indian bachelors

Unmarried Christian Indian women

Christian Indian boys

Indian men and women receiving instruction

in Christian doctrine (mixed group)

Indian families (gentiles)

Indian boys (gentiles)

Indian girls (gentiles)

10

7

3

8

Total Native Population

Agricultural Production

Crop Acreage in Cultivation

Corn

Beans

6 fanegas (9.6 acres)

3 almudes (1.5 acres)

1 garden grove for vegetables (for resident missionary)

Livestock Production

12 bulls (old and young)

$13 \mathrm{mi}$ ch cows

6 heifers (one-year old)

5 small calves

260 head of range cattle

Equipment and Tools

12 yoke of oxen

77 axes

7 hoes

2 adzes
1 framing-saw

2 iron bars

1 musket

Source: Fray Diego Xavier de Cervantes, Report of Mission San Bernardo, [October 25, 1706], AGN, P.I., 28: 340-341. 
TABLE 3. SAN JUAN BAUTISTA, 1727

Native Population

Number of Indian families

Dominant tribes represented: Sanas,

Mexcales, Filijayes and Pastalocos

Christian converts

210

Gentiles receiving instruction in

Christian doctrine

Total Native Population 240

Deaths: adult (since mission's founding) 207 children

Agricultural Production

Crop

Average Annual Harvest

Corn

Beans

800 fanegas (2,240 bushe7s)

25 fanegas (70 bushels)

Other crops of insignificant yield: chili, squash, cotton

Livestock Production

Cattle: $\quad 800$ head

Calves: $\quad 225$ head

Sheep: $\quad 752$ head

Goats: $\quad 400$ head

Separate flocks for training mission Indians: 220 head of sheep and goats

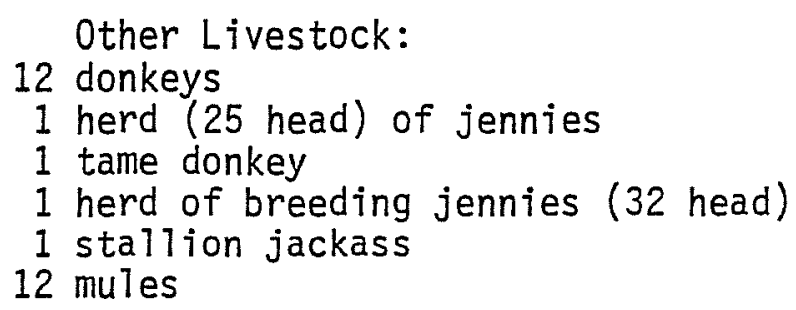

Source: Visita de las Misiones del Río Grande del Norte por Fray Miguel de Sevillano de Paredes, Comisario Visitador, October 6-November 6, 1727, AF, B.N. 
TABLE 4. SAN BERNARDO, 1727

Native Population

Number of Indian families

Dominant tribes represented: Paquaches,

Pastancoyas, Pachales and Pamaques

Christian converts

Gentiles receiving instruction in

Christian doctrine

Total Native Population 200

Deaths: adult (since the mission's founding) 156 children

Agricultural Production

Crop

Average Annual Harvest

Corn

Beans

400 fanegas (1,120 bushels)

6 to 9 fanegas ( 16 to 25 bushels)

Other crops of insignificant yield:

chili, squash, and other vegetables

Livestock Production

Cattle: 600 head

Calves: 200 head

Sheep: 465 head

Goats: 225 head

Sma11 goats:117 head

Separate flock of goats for

training mission Indians: 150 head

Other Livestock:

12 stallions

2 mares

35 donkeys

Source: Visita de las Misiones del Río Grande del Norte por Fray Miguel de Sevillano de Paredes, Comisario

Visitador, October 6-November 6, 1727, AF, B.N. 
TABLE 5. MISSION POPULATION STATISTICS, 1738 Mission San Juan Bautista

Members of Christian families (Mexacales) 81

Widowers

Members of Christian families (Pastalocos) 61

Widowers 10

Members of Christian families (Filijayas) 37

Members of Christian families (Pampopas) 9

Neophytes under instruction (Bozales), baptized 2

Neophytes under instruction (Pitas), baptized 27

Gentiles 60

$\begin{array}{ll}\text { Total Native Population } & 298\end{array}$

Mission San Bernardo

Christian families. 200

Widows and widowers 16

Gentiles (families) (Paches and Pacuaches) 347

Total Native Population 563

Source: Estéban L. Porti110, Apuntes para la Historia de Coahuila y Texas (Saltillo: Tipografia "El Golfo de Mexico" de Severo Fernandez, [1886]), pp. 283 and $290-291$. 


\section{NOTES}

1 Herbert Eugene Bolton and Thomas Maitland Marsha11, The Colonization of North America, 1492-1783 (New York: The Macmillan Company, 1920), p. 248.

2 Wigberto Jiménez Moreno, Estudios de flistoria Colonial (México: Instituto de Antropología e Historia, Serie Historia 1, 1977), p. 106.

An earlier interpretation of the 19th century emphasized the etymological derivation of Coahuila as "winged snake," from the contraction of coa (snake) and huila (flying wing). See Estéban L. Porti110, Apuntes para la Historia de Coahuila y Texas, ed. Amado Prado (Sa1til1o: Tipografía "El Golfo de México" de Severo Fernăndez [1886]), p. 18.

3 John. Francis Bannon, The Spanish Borderlands Frontier, 1513-1821 (New York: Holt, Rinehart and Winston, 1970), p. 5.

4 Edward W. Heusinger, Early Explorations and Mission Establishments in Texas (San Antonio: The Naylor Company, 1936), pp. 27-35.

5 Bolton and Marshal1, The Colonization of North America, pp. 248-249.

6 Michael B. McCloskey, The Formative Years of the Missionary College of Santa Cruz of Querétaro, 1683-1733 (Washington, D. C.: Academy of American Franciscan History, 1955), pp. 63-67; Heusinger, Early Explorations and Mission Establishments in Texas, pp. 36-40.

7 Marion A. Habig, "The Franciscan Provinces of Spanish North America," The Americas 1 (January 1945): pp. 337-338; Lino Gômez Canedo, ed., Primeras Exploraciones y Poblamiento de Texas (1686-1694) (Monterrey: Biblioteca del Instituto Tecnológico y de Estudios Superiores de Monterrey, 1968), p. viii; Diary of Fernando del Bosque, 1675, in Spanish Exploration in the Southwest, 1542-1706, ed. Herbert Eugene Bolton (New York: Charles Scribner's Sons, 1916), pp. 291-309.

8 Porti110, Apuntes de Coahuila y Texas, pp. 14-15.

The several Coahuiltecan tribes were Pajalates, Orejones, Pacoas, Alasapas, Pausanes, Pacuaches, Mescales, Pampopas, Pihuiques, Borrados, Sanipaos and Manos de Perro (Diccionario Porrúa de Historia, Biografía y Geografía de México, 2 vols. [Mexico: Editorial Porrua, S. A., 1970], 1:450).

9 Daniel S. Matson and Bernard L. Fontana, (ed. and trans.), "Introduction to the Bringas Report: A Microcosm of Endoctrination," Friar Bringas Reports to the King: Methods of Indoctrination on the Frontier of New Spain, 1796-97 (Tuscon: University of Arizona Press, 1977), pp. 7-16.

10 Theodosius Meyer, St. Francis and Franciscans in New Mexico (Santa Fe: The Historical Society of New Mexico and El Palacio Press, 1926), pp. 7-16.

11 Pius J. Barth, Franciscan Education and the Social Order in Spanish North America (1502-1821) (Chicago: University of Chicago Press, 1950), p. 321. 
12 Ibid.

13 Ibid., pp. 321-322.

14 McCloskey, Missionary College of Santa Cruz of querétaro, pp. 37-38, 46-47.

15 Matson and Fontana, Friar Bringas Reports to the King, p. 11.

16 Ibid., pp. 10-11, 13 .

17 Porti110, Apuntes de Coahuila y Texas, pp. 277-279. The governor of Coahuila, Francisco Cuervo y Valdez, commissioned Juan Martin Treviño to provide military protection for the friars on their journey into the Rio Grande frontier.

18 Isidro Félix de Espinosa, Cronica de los Colegios de Propaganda Fide de la Nueva España, ed. Lino G. Canedo (Washington, D.C.: Academy of American Franciscan History, 1964), p. 753.

19 Marion A. Habig, "San Juan Bautista's Fords," El Campanario 6 (March 1975): 3. In deference to the activities which transpired in the region, the crossings eventually acquired different names. For example, the lower crossing--known as Paso de Francia, Islas or Las Isletas--was the principal ford used most frequently by travelers in the colonial period. The upper crossing also had several names--Paso Pacuache, Diego Ramón or Paso del Nogal. The third crossing, located between the lower and upper fords, was called Paso de Cibolas, probably because of the buffalo that seasonally migrated to the river region.

20 Robert S. Weddle, "San Juan Bautista: Mother of Texas Missions," Southwestern Historical quarterly 71 (Apri1 1968): 545.

21 Robert F. Carter, The Tarnished Halo: The Story of Padre Francisco Hidalgo (Chicago: Franciscan Herald Press, 1973), pp. 51-52.

22 Benedict Luetenegger, ed. and trans., "Two Franciscan Documents on Early San Antonio, Texas: San Antonio and Father Antonio de 01 ivares, 0.F.M., 1716, and San Antonio and Fr: Benito Fernändez," The Americas 25 (October 1968): 193; Herbert Holzapfel, The History of the Franciscan Order, trans. Antonine Tibesar and Gervase Brinkmann (Teutopolis: St. Joseph Seminary, 1948), p. 570. For a comprehensive discussion of the Alabado and its use in the instruction of Indian families at the missions, see Notas in Espinosa, Crónica de los Colegios, pp. 594-595.

23 Weddle, "San Juan Bautista: Mother of Texas Missions," pp. 546-547; Marion A. Habig, The Alamo Chain of Missions: A History of San Antonio's Five old Missions (Chicago: Franciscan Herald Press, 1968), p. 31. Governor Cuervo y Valdez later moved north to New Mexico, where, in 1706, he was instrumental in the founding of the Villa of San Felipe de Alburquerque. (Gerald Thompson, "New Mexico History in New Mexico Magazine, An Annotated Bibliography [Part I]," Arizona and the West 17. [Autumn 1975]: 254).

24 Espinosa, Crónica de los Colegios, p. 756. 
25 Weddle, "San Juan Bautista: Mother of Texas Missions," p. 547; Habig, The Alamo Chain of Missions, p. 31; Espinosa, Crónica de los Colegios, p. 756.

The natives who congregated at San Bernardo in 1702 were Ocanes, Pachales and Pacuacianes. Extant sources have not disclosed the exact date of San Bernardo's foundation. A reliable authority cited the date of September 1703, with an impressive statistical report of temporal progress, all of which reinforced the credibility of an earlier founding the preceding year, 1702. (Portil10, Apuntes de Coahuila y Texas, p. 291).

26 Robert S. Weddle, San Juan Bautista: Gateway to Spanish Texas (Austin: University of Texas Press, 1968), p. 53; Weddle, "San Juan Bautista:

Mother of Texas Missions," p. 548; Carter, Tarnished Halo, pp. 79-80; Max L. Moorhead, The Presidio: Bastion of the Spanish Borderlands (Norman: University of Oklahoma Press, 1975), p. 29.

27 Fray Francisco Hidalgo to the Guardian of Santa Cruz de Querétaro, September 23, 1703, Archivo General de 1a Nación, Mexico City, Provincias Internas 28: 218. Hereinafter cited as AGN, P.I.

28 Weddle, "San Juan Bautista: Mother of Texas Missions," p. 548.

29 Espinosa, Crónica de los colegios, pp. 772-773.

30 Ibid.

31 Report of Fray Francisco Estēvez, Comisario Prefecto Apostólico, [College of] Santa Cruz de Querétaro, December 20, 1703, AGN, P.I., 28:217.

32 Habig, The Alamo Chain of Missions, p. 32.

33 Carter, Tarnished Halo, pp. 138-139.

$34 \mathrm{Fr}$. Joseph García [Father President of the Queretaran Missions in Coahuila], $\mathrm{Fr}$. Francisco Hidalgo and Fr. Antonio 0livares to the Father Guardian of Querétaro, Fray José Diez, May 17, 1704, in Carter, Tarnished Halo, pp. 137-138.

35 Diego Ramón to [Provincial Governor], May 20, 1705, AGN, P.I., 28:274-274v.

36 Fray Isidro de Espinosa, Report of Mission San Juan Bautista, October 23, 1706 , AGN, P.I., 28:339-340.

37 Fray Diego Xavier de Cervantes, Report of Mission San Bernardo [October 25, 1706], AGN, P.I., 28:340-341.

38 Carter, Tarnished Halo, pp. 80-81.

39 Fray Isidro de Espinosa, Fintos Espirituales de las Misiones pertenecientes al Colegio Apostólico de las Santa Cruz de Querétaro en los Confines de la Provincia de Coahuila y Nuevo Reyno de León, December 5, 1707, AGN, P.I, 28:434.

40 Fray Juan Pesertta, Fintos Espirituales, December 10, 1707, ibid. 
41 Fray Isidro de Espinosa, February 18, 1707, AGN, P.I., 28: 357.

42 Moorhead, The Presidio, pp. 27-46:

43. Visita de las Misiones del Río Grande del Norte por Fray Miguel de Sevillano de Paredes, Comisario Visitador, October 6-November 6, 1727; Archivo Franciscano, Caja 27, Biblioteca Nacional, Mexico City. Hereinafter cited as AF, B.N.

44 Ibid.

45 Ibid.

46 Ibid. Father Jeronimo de Ripalda, in the last decade of the 16th century, published a catechism that, within one generation, became the "most popular and widespread religious text in the Spanish dominions." First printed in 1591, Ripalda's Doctrina Christiana soon appeared in several editions in Spanish and in various native languages. The consensus among religious scholars was that in the Spanish empire there was no other catechism that could compete with it (Ernest J. Burrus, "The Author of the Mexican Council Catechisms," The Americas, 15 [October 1958]: 173-175).

47 Visita de... Fray Miguel de Sevillano de Paredes, October 6-November 6, 1727; AF, B.N.

Father Bartolomê Castaño, a Jesuit historian and missionary, began apostolic work among the Indians of the Sonora Valley in 1638. As late as the Spanish advance into Alta, California, the Fernandino friars still used a variant of Father Castano's method for catechetical instruction of the Indians. (Fintan Warren, "Jesuit Historians of Sinaloa-Sonora," The Americas, 18 [Apri1 1962]: 330; Maynard J. Geiger, The Life and Times of Fray Junipero Serra, O.F.M., 2 vols. [Washington, D.C.: Academy of American Franciscan History, 1959], I:78; Francis J. Weber, A History of San Buenaventura Mission [San Buenaventura: Roman Cathol ic Archdiocese of Los Angeles, 1977], pp. 31-35).

48 Carios E. Castaneda, Our Catholic Heritage in Texas, 1519-1936, 7 vols. (Austin: Von Boeckmann-Jones Company, 1936-1958), 2: 227-230.

49 Visita de . . Fray Miguel de Sevillano de Paredes, October 6-November 6, 1727; AF, B.N.

50 Ibid.

51 Juan de Acuña, Marqués de Casafuerte, to Brigadier Genera 1 Pedro de Rivera, 1727 (delivered at Presidio San Juan Bautista on December 27, 1727), Microfilm Collection, 01d Spanish Missions Historical Research Library, Mission San José in San Antonio, Texas. Hereinafter cited as MC, RLSJ.

52 Castañeda, Our Catholic Heritage in Texas, 2:267.

53 Habig, The Alamo Chain of Missions, pp. 125, 204.

54 Moorhead, The Presidio, p. 222. 
55 Padrởn de las Familias que no son Militares, y Habitan en este Presidio de San Juan Bautista del Río Grande del Norte para el cumplimiento de la Iglesia el Año de 1732, MC, RLSJ.

56 Porti110, Apuntes de Coahuila y Texas, pp, 288-290.

57 Ibid., pp. 283, 290.

58 Carta de Fray G. Muñoz, Vice Comisario de Misiones, con noticias varias sobre las misiones de Coahuila, [undated, ca, 1740], AF, B.N.

59 Copia de varios informes a favor de los misioneros de infieles, November 9 , 1740, AF, B.N.

60 Testimonio de Josê Flores, November 9, 1740, ibid.

61 Testimonio de Josê Menchaca, November 9, 1740, ibid.

62 Testimonio de Francisco Salinas; November 11, 17.40, ibid.

63 Testimonio de Capitản $D^{n}$ José Hernāndez, Justicia Mayor, November 12, 1740, ibid.

64 Fray Francisco Antonio López to the Father Guardian of College of Santa Cruz de Querétaro [Francisco Xavier Castellanos], Mission San Bernardo of the Río Grande, July 31, 1749, MC, RLSJ.

65 Ibid.

66 Mission San Juan Bautista's Record of Accounts to the College of Santa Cruz de Querétaro, July 1749, MC, RLSJ. The specific items of merchandise, by categories, included: cooking utensils--griddles, copper-plated pots and frying pans, grinding stones and mortars; ceramic ware--cups and plates from Puebla, jugs and pitchers from Patamban, Michoacän; food products-chocolate, sugar, salt, flour, rice, chick-peas, saffron; confection--boxes of candy; cutlery--clasp knives, large pointed knives; hardware--axes; textiles--coarse woolen cloth, silken fabrics; dry goods--small sheets; wearing apparel--shoes, hats, underwear, friar's habit of coarse woolen cloth; novelties--darning needles, ribbon, blue thread, necklace beads; sma11 accessories--washbasins, measuring tapes, small brushes; religious goods-rosaries, candle wax, sacramental wine, flour for Eucharistic wafers; and incidentals--tobacco, paper, soap and tallow.

67 Marion A. Habig, "Presidio and Missions of San Juan Bautista on the Rio Grande," El Campanario 5 (March 1974): 2.

68 Florence Johnson Scott, "Spanish Colonization of the Lower Rio Grande, 17471767," in Essays in Mexican History, ed. Thomas E. Cotner and Carlos E. Castañeda (Austin: The Institute of Latin American Studies, 1958; reprinted, Westport: Greenwood Press, 1972), pp. 3-20; Herbert Eugene Bolton, Texas in the Middle Eighteenth Century: Studies in Spanish Colonial History and Administration (New York: Russel1 \& Russe11, Inc., 1962), p. 239. 
69 Robert S. Weddle, The San Sabä Mission: Spanish Pivot in Texas (Austin: University of Texas Press, 1964), p. 39; Weddle, "San Juan Bautista: Mother of Texas Missions," p. 555.

70 Bolton, Texas in the Middle Eighteenth Century, pp. 255-256.

71 Visita de Tas Missiones [sic] de $S^{n}$ Juan Baupta y de $S^{n}$ Bernardo del Rfo Grande del Norte, en 1 a Prova de Coaguila, hecha Por el R. Pe Fr. Franco Xavier Ortiz, . . . Año de $1756 ;$ AF, B.N.

72 Ibid.

73 Bolton, Texas in the Middle Eighteenth Century, p. 80.

74 Weddle, "San Juan Bautista: Mother of Texas Missions," p. 556.

75 Lesley Byrd Simpson, ed., "Introduction," The San Sabä Papers: A Documentary Account of the Founding and Destruction of San Sabd Mission, trans. Paul D. Nathan (San Francisco: John Howe11--Books, 1958), p. ix.

76 Porti110, Apuntes de Coahuila y Texas, p. 291.

77 Weddle, "San Juan Bautista: Mother of Texas Missions," pp. 558-559; Hons Coleman Richards, "The Establishment of the Candelaria and San Lorenzo Missions on the Upper Nueces" (M.A. thesis, University of Texas at Austin, 1936), p. 49.

78 Elizabeth A. H. John, Storms Brewed in Other Men's Woreds: The Confrontation of Indians, Spanish, and French in the Southwest, 1540-1795 (College Station: Texas A\&M University Press, 1975), pp. 361-362; Habig, "Presidio and Missions of San Juan Bautista on the Rio Grande," p. 2; Richards, "The Establishment of the Candelaria and San Lorenzo Missions on the Upper Nueces," pp. 31-34.

79 Moorhead, The Presidio, pp. 47, 54-58; Magnus Morner, ed., "Introduction," The Expulsion of the Jesuits from Latin America (New York: Alfred A. Knopf, 1965), pp. 3, 13, 15, 24; Luis Navarro García, Don José de Gälvez y la Comandancia General de Las Provincias Internas del Norte de Nueva España (Sevilla: Escuela de Estudios Hispano-Americanos de Sevilla, 1964), pp. 133143; Troy S. Floyd, ed., "Introduction," The Bourbon Reformers and Spanish Civilization: Builders or Destroyers? (Boston: D.C. Heath and Company, 1966), pp. vii-xiii.

80 Sidney B. Brinckerhoff and Odie B. Faulk, Lancers for the King: A Study of the Frontier Military System of Northern New Spain, with a Translation of the Royal Regulations of 1772 (Phoenix: Arizona Historical Foundation, 1965), pp. $6-7,59-61$.

81 Moorhead, The Presidio, pp. 61-75.

82 Morner, The Expulsion of the Jesuits from Latin America, pp. 3-10.

83 Bannon, The Spanish Borderlands Frontier, pp. 148-150. 
84 Albert Stagg, The First Bishop of Sonora: Antonio de los Reyes, O.F.M. (Tucson: University of Arizona Press, 1976), p. 12; Matson and Fontana, Friar Bringas Reports to the King, pp. 17-18.

85 Castañeda, Our Catholic Heritage in Texas, 4: 262-263.

86 Ibid., pp. 264-265.

87 Ibid., p. 265.

88 Ymbentario de la Missión de San Juan Bautista del Río Grande del Norte, formado el dia 5 de Diciembre de 1772, en 1a Entrega a que los Padres Apostólicos hizieron de esta Missión a los Padres Observantes de la Provincia de Jalisco, MC, RLSJ.

89 Testimonio de los Vienes de la Missión de San Juan Bautista del Río Grande del Norte, Año 1772, quoted in Castañeda, Our Catholic Heritage in Texas; 4: 265.

90 Ymbentario de la Missión de San Bernardo, formado el dia 15 de Dizbre de 1772, en 1a Entrega que los Padres Apostólicos hizieron de esta Missión a los Padres Observantes de la Provincia de Xalisco, AF, B.N.

91 [Fray Juan Agustín Morfi], Descripciôn del Territorio del Pres ${ }^{0}$ de $S^{n}$ Juan Bautista del Rĩo Grande del Norte y su Jurisdición, Año de 1778 [January 23, 1778], AF, B.N.

92 Ibid.

93 Ibid.

94 Ibid.

95 Ibid.

96 Ibid.

97 Ibid.

98 Ibid.

99 Ibid.

100 Fray Juan Agustín de Morfi, Diario y Derrotero (1717-1781), ed. Eugenio de1 Hoyo and Malcolm D. McLean (Monterrey: Instituto Tecnológico y de Estudios Superiores de Monterrey, 1967), pp. 91-92; Pedro Zuloaga and Carlos Palomar, ed, and trans., Diccionario Enciclopedico de la Fé Católica (Mexico: Editorial Jus, S.A., 1953), pp. 526, 628.

101 Nota de las Misiones que hay en Estas Provincias con Expresion el Numero de Religiosos y Sinodos que Gozan [unsigned and undated, ca. 1779], AF, B.N. 
102 Lino Gómez Canedo, "Misiones del Colegio de Pachuca en el obispado del Nuevo Reino de Leôn," Estudios de Historia del Noreste (Monterrey: Sociedad Nuevoleonesa de Historia, Geografía y Estadística, 1972), p. 118; Informe Fray José David García to Obispo de Nuevo Santander, March 3, 1786, Ibid., p. 126.

103 Testimonio de Ynventario de los Bienes de la Misión de $S^{n}$ Juan Bapta del Río Gre del Norte, Año de 1781, Biblioteca Pública del Estado, Guadalajara, Jalisco. Hereinafter cited as BPE, G.J.

104 Testimonio del Inventario de Ta Misión de San Bernardo del Río Grande del Norte, Año de 1781, BPE, G.J.

705 Fray José David García to Obispo de Nuevo Santander, March 3, 1786, in Estudios de Historia del Noreste, p. 137.

106 Ibid.

107 Bernard E. Bobb, The Viceregency of Antonio Maria Burcareli in New Spain, 1771-1779 (Austin: University of Texas Press, 1962), p. 50; José Bravo Ugarte, Diocesis y obispos de la Iglesia Mexicana (Mexico: Editorial Jus, 1965), pp. 29, 66 .

$108 \mathrm{Fr}$. Ysidoro Puertollano to Viceroy of New Spain, Conde de Revilla Gigedo, November 16, 1793, in Estudios de Historia del Noreste, p. 158.

109 Ibid.

110 Conde de Revilla Gigedo, Carta dirigida a la Corte de España contestando a la Real Orden sobre establecimientos de Misiones, in Informe Sobre las Misiones1793--e Instrucción Reservada al Marqués de Branciforte--1794, ed. José Bravo Ugarte (Mexico: Editorial Jus, 1966), p. 63.

$111 \mathrm{Fr}$. Puertollano to Revi11a Gigedo, November 16, 1793, in Estudios de Historia del Noreste, pp. 159-160.

112 Castañeda, Our Catholic Heritage in Texas, 5: 46.

113 Porti110, Apuntes de Coahuila y Texas, p. 351.

114 Moorhead, The Presidio, pp. 92, 172.

115 Max L. Moorhead, The Apache Frontier: Jacabo Ugarte and Spanish-Indian Relations in Northern New Spain (Norman: University of Oklahoma Press, 1968), p. 287.

116 [Miguel José de Emparán], Extracto de Tas Novedade[s] de Enemigos ocurridas en la Jurisdición de Salti110, y la del Presidio de Río Grande en los dias que se declaran [JuTy 15, 1790], AGN, P.I., 160:214; Governor Emparán to Viceroy Conde de Revil1a Gigedo, July 29, 1790, AGN, P.I, , 160:224. 
117 [Antonio Toledo y Oquillas], Expediente y Padrones, 1797-1798, AGN, Ramo de Misiones, 20:102-107.

118 Captain Pedro Nolasco Carrasco to Governor Antonio Cordero, August 13, 1799, AGN, Misiones, 20:132-132v.

119 Antonio Toledo y Oquillas to Antonio Cordero, September 25, 1797, AGN, Misiones, 20:99-101.

120 - José Plácido de Morzón, Ynstancia del Vecindario del Presidio del Río Grande sobre repartimiento de tierras, Año de 1797, AGN, Misiones, 20:111-118.

121 Fray Pedro Rodena to Viceroy José Yturrigaray, September 17, 1804, AGN, Misiones, 20:312-312v.

122 Informe, Luis de la Garza to the Commandant General, December 29, 1807, AGN, Misiones, 20:400-404.

123 [Primo Feliciano Marin de Porras], Bishop of Nuevo Leōn, to Commandant General Nemesio Salcedo, November 1, 1808, AGN, Misiones, 20:415-415v.

124 Ibid.

125 Ibid.

126 Fray Francisco Gutiêrrez, Guardian of San Francisco de Pachuca, to Commandant General Nemesio Salcedo, March 4, 1809, AGN, Misiones, 20:427-428,

127 Fray Manuel Gorjón to Commandant General Nemesio Salcedo, June 19, 1809, AGN, Misiones, 20:431-433.

128 Fray Francisco Gutiêrrez, Lista de Religiosos del Colegio de Pachuca, February 10, 1810, AGN, Misiones, 20: 342-342v.

129 See Fétix D. Almaráz, Jr., Tragic Cavalier: Governor Manuel Salcedo of Texas, 1808-1813 (Austin: University of Texas Press, 1971).

130 Real Tribunal y Audiencia to the Fiscal de Real Hacienda, March 13, 1815, AGN, Misiones, 20:436-437.

131 Junta Superior de Real Hacienda to the Commandant General of the Interior Provinces, Apri1 17, 1815, AGN, Misiones, 20:438-441.

132 Luis Navarro Garcia, Las Provincias Internas en el Siglo XIX (Sevilla: Escuela de Estudios Hispano-Americanos de Sevilla, 1965), pp. 74-79.

133 Capitan Ramon Perea, 0ja de Servicio, February 1, 1817; Expediente No. 9, 1817 ; Ramon Perea to Joaquin de Arredondo, February 28, 1817; Arredondo to the Viceroy of New Spain, Apri1 30, 1817; and Manuel Rosales to Joaquin de Arredondo.

November 8, 1819, AGN, Misiones, 105:284-288v. 
134 [College Guardian of the] Apostolic College of Pachuca to Junta Superior de Rea] Hacienda, June 16, 1819, AGN, Misiones, 20:442-443v.

135 José Joaquîn Muñoz de Terân to Commandant General Joaquin de Arredondo, September 22 and November 29, 1819, AGN, P. I, , 260:385-386v.

136 Commandant General Joaquin de Arredondo to the Viceroy of New Spain [Juan Ruiz de Apodaca], June 29, 1820, AGN, P.I., 260:404-405v.

137 Fểix D. A7maráz, Jr., "Governor Antonio Martínez and Mexican Independence in Texas: An Orderly Transition, "The Permian Heistorical Annual 15 (December 1975): 45-50. 
BIBLIOGRAPHY

\section{ARCHIVAL SOURCES}

\section{Guadalajara, Jalịsco, Mẹ́xico}

Testimonio del Inventario de la Misión de San Bernardo del Río Grande del Norte, Año de 1781. Biblioteca Pública del Estado,

Testimonio de Ynventario de los Bienes de la Misión de $S^{n}$ Juan Bap ${ }^{\text {ta }}$ del Río Gre del Norte, Año de 1781. Biblioteca Publica del Estado.

\section{Mexico City, Mëxico}

Commandant Genera] Joaquin de Arrendondo to the Viceroy of New Spain [Juan Ruiz de Apodaca], June 29, 1820. Archivo General de 1a Nación, Provincias Internas, vol. 260, pp. 404-405v.

Fray Diego Xavier de Cervantes, Report of Mission San Bernardo, October 25, 1706. Archivo General de 1a Nación, Provincias Internas, vol. 28, pp. 340-341.

[College Guardian] of the Apostolic College of Pachuca to Junta Superior de Real Hacienda, June 16, 1819. Archivo General de la Nación, Ramo de Misiones, vol. 20, pp. $443-443 v$.

Copia de varios informes a favor de los misioneros de infieles, November 9, 1740. Archivo Franciscano, Biblioteca Nacional de México.

Luis de 1a Garza, Informe to the Commandant General, December 29, 1807. Archivo General de la Nación, Ramo de Misiones, vol. 20, pp. 400-404.

Governor [Miguel José de] Emparán to Viceroy Conde de Revilla Gigedo, July 29, 1790. Archivo General de la Nación, Provincias Internas, vol. 160, p. 224.

[Miguel José de Emparán.] Extracto de las Novedade[s] de Enemigos ocurridas en la Jurisdición de Saltillo, y la del Presidio de Rio Grande en los dias que se declaran, [july 15, 1790]. Archivo General de la Nación, Provincias Internas, vol. 160, p. 214.

Fray Isidro de Espinosa, February 18, 1707. Archivo General de 1a Nación, Provincias Internas, v01. 28, p. 357.

- Fintos Espirituales de las Misiones pertenecientes al Colegio Apostólico de la Santa Cruz de Querêtaro en los Confines de la Provincia de Coahuila y Nuevo Reyno de Leôn, December 5, 1707. Archivo General de Nación, Provincias Internas, vol. 28, p. 434. 
- Report of Mission San Juan Bautista, October 23, 1706. Archivo General de la Nación, Provincias Internas, vol. 28, pp. 339-340.

Report of Fray Francisco Estêvez, Comisario Prefecto Apostólico, [College of] Santa Cruz de Querétaro, December 20, 1703. Archivo General de la Naciōn, Provincias Internas, vol. 28, p. 217 ,

Testimonio de José Flores, November 9, 1740; Copia de varios informes a favor de 10 misioneros de infieles. Archivo Franciscano, Biblioteca Nacional de México.

Fray Manuel Gorjón to Commandant General Nemesio Salcedo, June 19, 1809. Archivo General de la Nación, Ramo de Misiones, vol. 20, pp. 431-433.

Fray Francisco Gutiêrrez, Guardian of San Francisco de Pachuca, to Commandant General Nemesio Salcedo, March 4, 1809. Archivo General de la Nación, Ramo de Misiones, vol. 20, pp. 427-428.

- Lista de Religiosos del Colegio de Pachuca, February 10, 1810. Archivo General de 1a Nación, Ramo de Misiones, vol, 20, pp. 342-342v.

Testimonio de Capitán $D^{n}$ José Hernăndez, Justicia Mayor, November 12, 1740; Copia de varios informes a favor de los misioneros de infieles. Archivo Franciscano, Biblioteca Nacional de México.

Fray Francisco Hidalgo to the Guardian of Santa Cruz de Querétaro, September 23, 1703. Archivo General de 1a Naciōn, Provincias Internas, vo1. 28, p. 218.

Junta Superior de Real Hacienda to the Commandant General de la Nación, Ramo de Misiones, vol. 20, pp. 438-441.

[Primo Feliciano Marín de Porras], Bishop of Nuevo León, to Commandant General Nemesio Salcedo, November 1, 1808. Archivo General de la Nación, Ramo de Misiones, vol. 20, pp. 415-415v.

Testimonio de José Menchaca, November 9, 1790; Copia de varios informes a favor de los misioneros de infieles. Archivo Franciscano, Biblioteca Nacional de México.

[Fray Juan Agustin Morfi.] Descripción del Territorio del Pres $^{0}$ de $S^{n}$ Juan Bautista del Río Grande del Norte y su Jurisdición, Año de 1778 (January 23, 1778). Archivo Franciscano, Biblioteca Nacional de México.

José Plácido de Morzón, Ynstancia del Vecindario del Presidio del Río Grande sobre repartimiento de tierras, Año de 1797. Archivo General de la Nación, Ramo de Misiones, vol. 20, pp. 111-118.

Carta de Fray G. Muñoz, Vice Comisario de Misiones, con noticias varias sobre las misiones de Coahuila [undated, circa 1740]. Archivo Franciscano, Biblioteca Nacional de México.

José Joaquîn Muñoz de Terăn to Commandant General Joaquín de Arredondo, September 22 and November 9, 1819. Archivo General de 1a Nación, Provincias Internas, vol. 260, pp. 385-385v. 
Captain Pedro Nolasco Carrasco to Governor Antonio Cordero, August 13, 1799. Archivo General de la Nación, Ramo de Misiones, vol. 20, pp. 132-132v.

Nota de Tas Misiones que hay en Estas Provincias con Expresión el Número de Religiosos y Sinodos que Gozan [unsigned and undated; circa 1779]. Archivo Franciscano, Biblioteca Nacional de México.

[Francisco Xavier Ortiz.] Visita de las Missiones [sic] de $S^{n}$ Juan Baup ${ }^{\text {ta }} y$ de $S^{n}$ Bernardo del Río Grande del Norte, en la Prova de Coaguila, hecha Por el R. Pe Fr. Franco Xavier Ortiz,. . Año de 1756. Archivo Franciscano, Biblioteca Nacional de México.

Capitán Ramón Perea, Oja de Servicio, February 1, 1817; Expediente No. 9, 1817. Archivo General de la Nación, Provincias Internas, vo1. 105, pp. 284-288v.

Fray Juan Pesertta, Fintos Espirituales de las Misiones pertenecientes al Colegio Apostólico de la Santa Cruz de Querétaro en los Confines de la Provincia de Coahuila y Nuevo Reyno de Leōn, December 10, 1707. Archivo General de la Nación, Provincias Internas, vol. 28, p. 434.

Diego Ramón to [Provincial Governor of Coahuila], May 20, 1705. Archivo General de la Nación, Provincias Internas, vol.28, pp. 274-274v.

Real Tribunal y Audiencia to the Fiscal de Real Hacienda, March 13, 1815. Archivo General de Ta Nación, Ramo de Misiones, vol. 20, pp. 312-321v.

Fray Pedro Rodena to Viceroy Joše Yturrigaray, September 17, 1804. Archivo General de la Nación, Ramo de Misiones, vol. 20, pp. 312-312v.

Testimonio de Francisco Salinas, November 11, 1740; Copia de varios informes a favor de los misioneros de infieles. Archivo Franciscano, Biblioteca Nacional de México.

[Sevillano de Paredes.] Visita de las Misiones del Río Grande del Norte por Fray Miguel de Sevillano de Paredes, Comisario Visitador, October 6November 6, 1727. Archivo Franciscano, Biblioteca Nacional de México.

[Antonio Toledo y Oquillas.] Expediente y Padrones, 1797-1798. Archivo Genera] de la Nación, Ramo de Misiones, vol. 20, pp. 102-107.

- Letter to Antonio Cordero, September 25, 1797. Archivo General de 1a Naciōn, Ramo de Misiones, vol. 20, pp. 99-101.

Ymbentario de la Missión [sic] de San Bernardo, formado el dia 15 de Dizbre de 1772, en la Entrega que Tos Padres Apostólicos hizieron de esta Missión a los Padres Observantes de la Provincia de Xalisco. Archivo Franciscano, Biblioteca Nacional de México. 


\section{SAN ANTONIO, TEXAS}

Juan de Acuña, Marqués de Casafuerte, to Brigadier General Pedro Rivera, December 27, 1727. Microfilm Collection, 01d Spanish Missions Historical Research Library, San Josê Mission.

Fray Francisco Antonio López to the Father Guardian of the College of Santa Cruz de Querëtaro [Francisco Xavier Castellanos], JuTy 31, 1749. Microfilm Collection, 01d Spanish Missions Historical Research Library, San José Mission.

Padrón de las Familias que no son Militares, y Habitan en este Presidio de San Juan Bautista del Río Grande del Norte para el cumplimiento de la Iglesia en Año de 1732. Microfilm Collection, 01d Spanish Missions Historical Research Library, San Jösé Mission.

Ymbentario de la Missión [sic] de San Juan Bautista del Río Grande del Norte, formado el dia 5 de Diciembre de 1772, en la Entrega a que 1os Padres Apostólicos hizieron de esta Missión a los Padres Observantes de 1a Provincia de Jalisco. Microfilm Collection, 0ld Spanish Missions Historical Research Library, San Josë Mission.

\section{PRIMARY SOURCES \\ Printed}

Brinckerhoff, Sidney B., and Odie B. Faulk, Lancers for the King: A Study of the Frontier Military System of Northern New Spain, with a Translation of the Royal Regulations of 1772. Phoenix: Arizona Historical Foundation, 1965.

[De1 Bosque, Fernando.] Diary of Fernando de 7 Bosque, 1675, in Spanish Explorations in the Southwest, 1542-1706, ed, by Herbert Eugene Bo7ton. New York: Charles Scribner's Sons, 1916.

Espinosa, Isidro Fêlix de. Crônica de los colegios de Propaganda Fide de $7 a$. Nueva España, ed. Lino G; Canedo. Washington: Academy of American Franciscan History, 1964.

[Fray José David García.] Informe, Fray José David García to Obispo de Nuevo Santander, March 3, 1786, in Lino Gómez Canedo, "Misiones del Colegio de Pachuca en el Obispado del Nuevo Reino de León." Estudios de Historia del Noreste, pp. 126-145. Monterrey: Sociedad Nuevoleonesa de Historia, Geografía y Estadîstica, 1972.

[Fr. Joseph Garcia et a1.] Fr. Joseph Garcia, Fr. Francisco Hidalgo, and Fr. Antonio 01ivares to the Father Guardian of Querêtaro; Fray Jose Diez, May 17, 1704, in Robert F. Carter, The Farnished Ha 70: The Story of Padre Francisco Hidalgo. Chicago: Franciscan Herald Press, 1973.

Gómez Canedo, Lino (ed.). Primeras Exploraciones y Poblamiento de Texas (16861694). Monterrey: Biblioteca del Instituto Tecnológico de Estudios Superiores de Monterrey, 1968. 
Leutenegger, Benedict (ed. and trans.). "Two Franciscan Documents of Early San Antonio, Texas: San Antonio and Father Antonio de 01 ivares, 0.F.M., 1716, and San Antonio and Fr. Benito Fernández." The Americas, XXV (October, 1968), 191-206.

Matson, Daniel S., and Bernard L. Fontana (trans. and ed.). Friar Bringas Reports to the King: Methods of Indoctrination on the Frontier of New Spain, 1796-97. Tucson: University of Arizona Press, 1977.

Morfi, Fray Juan Agustin de. Diario y Derrotero (1777-1781), ed. by Eugenio del Hoyo and Malcolm D. McLean. Monterrey: Instituto Tecnológico y de Estudios Superiores de Monterrey, 1967.

[Fr. Ysidoro Puertollano.] Fr. Ysidoro Puertollano to Viceroy of New Spain, Conde de Revilla Gigedo, November 16, 1793, in Lino Gómez Canedo, "Misiones del Colegio de Pachuca en el Obispado del Nuevo Reino de León," Estudios de Historia del Noreste, pp. 153-163. Monterrey: Sociedad Nuevoleonesa de Historia, Geografía y Estadistica, 1972.

Revilla Gigedo, Conde de. Informe Sobre las Misiones--1793--e Instrucciōn Reservada al Marqués de Branciforte--1794, ed. by José Bravo Ugarte. Mexico: Editorial Jus, 1966.

Simpson, Lesley Byrd (ed.). The San Sabá Papers: Documentary Account of the Founding and Destruction of San Sabá Mission, trans, by PauT D. Nathan. San Francisco: John Howe11--Books, 1958.

\section{Unpubtished}

Richards, Hons Coleman. "The Establishment of the Candelaria and San Lorenzo Missions on the Upper Nueces." M. A. thesis, University of Texas at Austin, 1936.

\section{SECONDARY SOURCES}

\section{Books}

Almarăz, Jr.; Félix D. Tragic Cavalier: Governor Manuel Salcedo of Texas, 1808-1813. Austin: University of Texas Press, 1971.

Bannon, John Francis. The Spanish Borderlands Frontier, 1513-1821. New York: Holt, Rinehart and Winston, 1970.

Barth, Pius J. Franciscan Education and the Social Order in Spanish North America (1502-1821). Chicago: University of Chicago Press, 1950.

Bobb, Bernard E. The Viceregency of Antonio María Bucareli in New Spain, 1771-1779. Austin: University of Texas Press, 1962. 
Bolton; Herbert Eugene. Texas in the Middle Eighteenth Century: Studies in Spanish Colonial History and Administration. New York: Russe71 \& Russel1, Inc., 1962.

Bolton, Herbert Eugene, and Thomas Maitland Marshal1. The Colonization of North America, 1492-1783. New York: The Macmi11an Company, 1920.

Bravo Ugarte, José. Diócesis y Obispos de la Iglesia Mexicana. Mexico: Editorial Jus, S. A., 1965.

Carter, Robert F. The Tarnished Halo: The Story of Padre Francisco Hidalgo. Chicago: Franciscan Herald Press, 1973.

Castañeda, Carlos E. Our Catholic Heritage in Texas, 1519-1936. 7 vols. Austin: Von Boeckmann-Jones Company, 1936-1958.

Floyd, Troy S., (ed.) The Bourbon Reformers and Spanish Civilization: Builders or Destroyers? Boston: D. C. Heath and Company, 1966.

Geiger, Maynard J. The Life and Times of Fray Junípero Serra, O.F.M. 2 vols. Washington: Academy of American Franciscan History, 1959.

Habig, Marion A. The Alamo Chain of Missions: A History of San Antonio's Five old Missions. Chicago: Franciscan Herald Press, 1968.

Heusinger, Edward W. Early Explorations and Mission Establishments in Texas. San Antonio: The Naylor Company, 1936.

Holzapfel, Herbert. The History of the Franciscan Order. Translated by Antoine Tibesar and Gervase Brinkmann. Teutopolis: St. Joseph Seminary, 1948.

Jiménez Moreno, Wigberto. Estudios de Historia Colonial. Mexico: Instituto Nacional de Antropologia e Historia, 1977.

John, Elizabeth A. H. Storms Brewed in Other Men's Worlds: The Confrontation of Indians, Spanish, and French in the Southwest, 1540-1795. College Station: Texas A\&M University Press, 1975.

McCloskey, Michael B. The Formative Years of the Missionary College of Santa Cruz of Querétaro, 1683-1733. Washington: Academy of American Franciscan History, 1955.

Meyer, Theodosius. St. Francis and Franciscans in New Mexico. Santa Fe: The Historical Society of New Mexico and El Palacio Press, 1926.

Moorhead, Max L. The Apache Frontier: Jacobo Ugarte and Spanish-Indian Relations in Northern New Spain. Norman: University of Oklahoma Press, 1975.

- The Presidio: Bastion of the Spanish Borderlands. Norman: University of $0 \mathrm{k} 7$ ahoma Press, 1975. 
Morner, Magnus, ed. The Expulsion of the Jesuits from Latin America, New York: Alfred A. Knopf, 1965.

Navarro Garcia, Luis. Don José de Gálvez y la Comandancia General de las Provincias Internas del Norte de Nueva España. Sevilia: Escuela de Estudios Hispano-Americanos de Sevil1a, 1964.

- Las Provincias Internas en el Siglo XIX. Sevilla: Escuela de Estudios Hispano-Americanos de Sevilla, 1965.

Portil1o, Estéban L. Apuntes para la Historia de Coahuila y Texas. Edited by Amado Prado. Salti170: Tipografía "E1 Golfo de México" de Severo Fernández, 1886.

Stagg, Albert. The First Bishop of Sonora: Antonio de los Reyes, 0.F.M. Tucson: University of Arizona Press, 1977.

Weber, Francis J. A History of San Buenaventura Mission. San Buenaventura: Roman Catholic Archdiocese of Los Angeles, 1977.

Weddle, Robert S. San Juan Bautista: Gateway to Spanish Texas. Austin: University of Texas Press, 1968.

- The San Sabá Mission: Spanish Pivot in Texas, Austin: University of Texas Press, 1964.

Zuloaga, Pedro, and Carlos Palomar, (ed. and trans.) Diccionario Enciclopedico de la Fé Católica. Mexico: Editorial Jus, S.A., 1953.

\section{Periodical Articles}

Almarăz, Jr., Fêlix D. "Governor Antonio Martínez and Mexican Independence in

"Texas: An Orderly Transition.". The Permian Historical Annual, 15 (December, 1975): $44-55$.

Burris, Ernest J. "The Author of the Mexican Council Catechisms," The Americas, 15 (October, 1958): 171-178.

Gómez Canedo, Lino. "Misiones del Colegio de Pachuca en el Obispado del Nuevo Reino de Leôn." Estudios de Historia del Noreste (Monterrey: Sociedad Nuevoleonesa de Historia, Geografía y Estadística, 1972): 117-125.

Habig, Marion A. "Presidio and Missions of San Juan Bautista on the Rio Grande." El Campanario, 5 (March, 1974): 1-3.

"San Juan Bautista's Fords." El Campanario, 6 (March, 1975): 2-5. "The Franciscan Provinces of Spanish North America." The Americas, 1 (January, 1945): 330-344. 
Scott, Florence Johnson. "Spanish Colonization of the Lower Rịo Grande, 1747-1767." Essays in Mexican History. Edited by Thomas E. Cotner and Carlos E. Castañeda (Austin: The Institute of Latin American Studies, 1958; Westport: Greenwood Press, 1972): 3-20.

Thompson, Gerald. "New Mexico's History in New Mexico Magazine, An Annotated Bibliography (Part I)." Arizona and the West, 17 (Autumn, 1975): 245-278.

Warren, Fintan. "Jesuit Historians of Sinaloa-Sonora." The Americas, 8 (Apri1, 1962): 329-339.

Weddle, Robert S. "San Juan Bautista: Mother of Texas Missions." Southwestern Historical Quarterly, 71 (Apri1, 1968): 542-563. 